\title{
Article \\ Experimental Comparison of Heating Emitters in Mediterranean Climate
}

\author{
Rosa Francesca De Masi ${ }^{1, *}$, Silvia Ruggiero ${ }^{1}(\mathbb{D})$ and Giuseppe Peter Vanoli ${ }^{2}$ \\ 1 DING-Department of Engineering, University of Sannio, 82100 Benevento, Italy; sruggiero@unisannio.it \\ 2 Department of Medicine and Health Sciences-Vincenzo Tiberio, University of Molise, \\ 86100 Campobasso, Italy; giuseppe.vanoli@unimol.it \\ * Correspondence: rfdemasi@unisannio.it; Tel.: +39-(0)824-3055577
}

Citation: Masi, R.F.D.; Ruggiero, S.; Vanoli, G.P. Experimental Comparison of Heating Emitters in Mediterranean Climate. Appl. Sci. 2021, 11, 5462. https://doi.org/ 10.3390/app11125462

Academic Editor: Demis Pandelidis

Received: 20 May 2021

Accepted: 10 June 2021

Published: 12 June 2021

Publisher's Note: MDPI stays neutral with regard to jurisdictional claims in published maps and institutional affiliations.

Copyright: (c) 2021 by the authors. Licensee MDPI, Basel, Switzerland. This article is an open access article distributed under the terms and conditions of the Creative Commons Attribution (CC BY) license (https:// creativecommons.org/licenses/by/ $4.0 /)$.

\begin{abstract}
The need to increase the level of quality of indoor environments requires an extremely accurate definition of the microclimatic requisites to guarantee, in the spaces where people live and work, global and local conditions of comfort, considering, at the same time, the aspects related to energy savings and environmental sustainability. In this framework, the paper proposes a comparison of indoor parameters for three different types of heating emitters: fan-coils, baseboards heaters, and radiant floor systems. The comparison is based on seasonal monitoring performed in a test-room located in a Mediterranean climate; it can simulate an insulated room with office usage. The proposed indices demonstrate that the floor radiant system is characterized by lower horizontal and vertical differences in air temperature distribution that can guarantee more comfortable conditions and lower heat losses. The operative temperature is often higher than the neutral point; thus, management with a lower set-point temperature should be experimented with in further studies. More generally, the introduced method could help designers to choose the proper system and management strategy with the dual purpose to select a comfortable but energy savings-oriented operating temperature.
\end{abstract}

Keywords: thermal comfort; emitters; experimental measures; temperature distribution

\section{Thermal Comfort: Indoor Plant Emitters and Control Strategies}

According to the definition by ASHRAE [1,2], thermal comfort is the condition of mind that expresses satisfaction with the thermal environment. It has a wide connotation, also including physiological and psychological aspects in addition to ambient characteristics $[3,4]$. The overall thermal sensation and the degree of discomfort of people exposed to moderate thermal environments can be determined according to international standard EN ISO 7730 [5]. This standard allows the analytical determination and interpretation of thermal comfort conditions through the calculation of the predicted mean vote (PMV) and predicted percentage of dissatisfied (PPD), as well as the analysis of local thermal discomfort phenomena (vertical air temperature differences, warm and cool floors, drafts, radiant temperature asymmetries).

The PMV index, based on an analysis of the heat balance equation for the human body, takes into account the influence of thermal comfort factors (air temperature, air velocity, mean radiant temperature, humidity, clothing, and activity) by means of a value on a 7-point scale ( 0 is neutral, +1 is slightly warm, and -1 is slightly cool). The PPD is correlated to the PMV value by means of a mathematical equation that reveals a small percentage of dissatisfied (5\%) under thermal neutrality conditions (i.e., PMV =0).

According to the criteria of [5], three categories can be identified for classifying the thermal environment. These are shown in Table 1, where DR is the draught rate; $\mathrm{T}_{\mathrm{f}}$ indicates the value of an acceptable floor temperature; $\Delta \mathrm{T}_{\mathrm{pr}, \mathrm{wc}}$ is the radiant asymmetry for a warm ceiling; $\Delta \mathrm{T}_{\mathrm{pr}, \mathrm{cc}}$ is the radiant asymmetry for a cool ceiling; $\Delta \mathrm{t}_{\mathrm{pr}, \mathrm{ww}}$ is the radiant asymmetry for a warm wall; $\Delta \mathrm{T}_{\mathrm{pr}, \mathrm{cw}}$ is the radiant asymmetry for a cold wall; and finally in the last 
column there is the vertical difference between the value of air temperature measured at $1.1 \mathrm{~m}\left(\mathrm{~T}_{\mathrm{a} \_1.1}\right)$ and at $0.1 \mathrm{~m}\left(\mathrm{~T}_{\mathrm{a} \_0.1}\right)$.

Table 1. Categories of thermal comfort and local discomfort according to ISO 7730.

\begin{tabular}{|c|c|c|c|c|c|c|c|c|c|}
\hline & \multicolumn{2}{|c|}{ Global Comfort } & \multicolumn{7}{|c|}{ Local Discomfort } \\
\hline & PMV & PPD (\%) & $\mathrm{T}_{\mathrm{f}}\left({ }^{\circ} \mathrm{C}\right)$ & DR (\%) & $\begin{array}{c}\Delta \mathrm{T}_{\mathrm{pr}, \mathrm{wc}} \\
\left({ }^{\circ} \mathrm{C}\right)\end{array}$ & $\begin{array}{c}\Delta \mathrm{T}_{\mathrm{pr}, \mathrm{cc}} \\
\left({ }^{\circ} \mathrm{C}\right)\end{array}$ & $\begin{array}{c}\Delta \mathrm{T}_{\mathrm{pr}, \mathrm{ww}} \\
\left({ }^{\circ} \mathrm{C}\right)\end{array}$ & $\begin{array}{c}\Delta \mathrm{T}_{\mathrm{pr}, \mathrm{cw}} \\
\left({ }^{\circ} \mathrm{C}\right)\end{array}$ & $\begin{array}{c}\mathrm{T}_{\mathrm{a}, 1.1}-\mathrm{T}_{\mathrm{a}, 0.1} \\
\left({ }^{\circ} \mathrm{C}\right)\end{array}$ \\
\hline A & -0.20 to 0.20 & $<6$ & $19-29$ & $<10$ & $<5$ & $<14$ & $<23$ & $<10$ & $<2$ \\
\hline B & -0.50 to 0.50 & $<10$ & $19-29$ & $<20$ & $<5$ & $<14$ & $<23$ & $<10$ & $<3$ \\
\hline $\mathrm{C}$ & -0.70 to 0.70 & $<15$ & $17-31$ & $<30$ & $<7$ & $<18$ & $<35$ & $<13$ & $<4$ \\
\hline
\end{tabular}

Designers must take into account these criteria, not only for assuring occupant wellbeing but also for optimizing the whole building's HVAC system's energy efficiency, as discussed by D'ambrosio Alfano et al. [6]. In this regard, researchers usually investigate the relationship between comfort and plant design focusing on two aspects: difference between HVAC types [7], and selection of the optimized control strategy [8].

Regarding the first item, Gendelis et al. [9], comparing three different systems, found that only the electric heater satisfies the requirements of the A category of the thermal environment, with $20^{\circ} \mathrm{C}$ indoor temperature and a normal ventilation regime. The experimental data collected in the building of Tsinghua University [10] suggest that in continuous heating, there is no significant difference between radiant and convective systems in terms of mean radiant temperature, indoor humidity, and noise issues. Despite split-type systems for cooling being popular in many countries, da Silva Junior et al. [11] underlined that these systems commonly promote high gradients of both temperature and air velocity in rooms and these can cause thermal discomfort. Han et al. [12] showed that when implemented in industrial factory buildings, radiant heating can save over $10 \%$ energy compared to convection heating. However, Karman et al. [13], elaborating data of a survey from 3892 respondents in 60 office buildings located in North America, showed that radiant and all-air buildings have equal indoor environmental quality, including acoustic aspects. Similarly, by means of measurements and questionnaires in Dutch primary schools, Zeiler and Boxem [14] found that there is no significant difference in the perceived comfort between heated by radiant floor heating systems and by convection heating systems. Inard et al. [15], with a simplified model of dwelling-cells, concluded that the hot-water heated-floor system provides a good compromise between energy consumption and thermal comfort. The electrical heated ceiling has an equivalent consumption with a low level of thermal comfort, and the localized heat sources give very satisfactory comfort conditions, but the energy consumption is slightly higher. Petráš and Kalús [16] showed with experimental results that infrared gas heaters in a workplace provide an immediate effect on thermal comfort when compared with other heating systems. However, Ghaddar et al. [17] explored a radiant stove space-heating unit, underlining that it is possible to save $14 \%$ of the heating energy by changing the stove position in the room with the same level of comfort. Three electric heaters were compared by Léger et al. [18] in a bi-climatic chamber. The results showed that the convector does not consume less energy, since it heated the adjacent windows and wall less than the radiant heater and baseboard heater. Simulating a radiant heating system at different locations, with different surface areas and corresponding temperatures, Tye-Gingras and Gosselin [19] showed that all three parameters could affect energy consumption and thermal comfort. Instead, Sevilgen and Kilic [20] found that energy consumption can be significantly reduced while increasing the thermal comfort by using better-insulated outer wall materials and windows.

Despite these results, according to Halawa et al. [21], study of radiant systems should continue in terms of system design, configuration, and control. For instance, air movement seems to be a critical issue since some studies, such as [22], affirm that radiant heating systems led to more thermal comfortable votes due to less air movement, and others [23] report that occupants might doubt the freshness of the air since they cannot feel the air 
movement. In this field, Corgnati et al. [24] proposed the coupling of primary air systems, and Causone et al. [25] verified the effectiveness of displacement ventilation for improving the indoor air quality.

Few studies are available on baseboard heaters such as the one proposed by Bagheri et al. [26]. They found that a baseboard heater with a convector fin can increase the performance by up to $42 \%$ and $94 \%$, respectively, compared to the conventional fins. Similarly, Shobi et al. [27] revealed that the total thermal power of the modified radiant baseboard with higher free convection is $34 \%$ higher than that of the conventional one.

Finally, the review analysis of Karmann et al. [28] pointed out that five studies established a thermal comfort preference between all-air and radiant systems, and three studies showed a preference for radiant systems. However, more recently, by means of experiments in a test chamber, Sun et al. [29] found that there was no significant thermal comfort difference during the steady stage of convective and radiative heaters.

On the other hand, in recent years, several studies focused on approaches and strategies to control building HVAC systems for reducing energy consumption and polluting emissions without compromising thermal comfort. Lin et al. [30] experimentally verified an optimized control strategy for fan-coil units achieving 39.71\% energy conservation. Sánchez-García et al. [31] found that the adaptive approach in Mediterranean cities can guarantee reductions in cooling consumption (around 50-60\%) in contrast with discrete savings for heating (around 20\%). Considering the temperature set point strategies, Date et al. [32] obtained peak demand reductions of up to $10 \%$ and $25 \%$ when the conventional night time setback temperature profile was respectively changed with a one hour or two hours ramp with baseboards. For the 'hot summer-cold winter' climatic region of China, Wang et al. [33] hypothesized a heating temperature set point of $17-18{ }^{\circ} \mathrm{C}$ based on a lumped-parameter four-node steady-state model. By means of simulations for typical USA single-family homes, Moon and Han [34] found a linear increase of $5.4 \% /{ }^{\circ} \mathrm{C}$ for heating consumption in a cold climate passing from 15.6 to $26.7^{\circ} \mathrm{C}$. According to Ghahramani et al. [35], the potential savings from selecting daily optimal set-points in the range of $22.5 \pm 3{ }^{\circ} \mathrm{C}$ for small, medium, and large office buildings would lead to $10.09-37.03 \%$, $11.43-21.01 \%$, and $6.78-11.34 \%$ savings, respectively, depending on the climate. BienvenidoHuertas et al. [36] demonstrated that the set-point values prefixed by EN 16798-1:2019 for new buildings can bring significant savings with respect to the static model.

In field measurements of indoor environments and occupant satisfaction, surveys were used in [37] to evaluate optimized strategies to manage the HVAC system in an existing office building - the Town Hall of Viborg, Denmark. Proposed optimization scenarios (lower set point temperature, adoption of $\mathrm{CO}_{2}$ sensors for the openings) brought a $21-37 \%$ reduction of heating consumption and thermal comfort improvement by $7-12 \%$. Hang and Kim [38] introduced an enhanced model-based predictive control practical system considering both the PMV index and the outdoor environment conditions. Tushar et al. [39] proposed a control system in which each occupant can input their preferences on the set-point temperature. It was shown that the policy can benefit occupants by increasing the aggregated thermal comfort and also building management in terms of reducing the cost for maintaining a set-point temperature. Wang et al. [40] showed with two test-beds at Guangzhou and Lanzhou in China that the satisfaction-based control can achieve a more comfortable and stable indoor thermal environment than set-point-based control. Moreover, the satisfaction-based control reduced consumption by about $15.3 \%$ and $11.9 \%$ in these test-beds. In a small office building, for five climate zones representative of the United States, Nikdel et al. [41] found that occupancy-based strategies could bring $22-50 \%$ and $47-87 \%$ reduction in electricity and natural gas use, respectively, compared to no thermostat control. Considering the response of 1400 thermal comfort surveys in a naturally ventilated building, Yongchao et al. [42] found that with adaptive control behaviors, occupants were thermally neutral and satisfied from 18 to $27^{\circ} \mathrm{C}$. Their satisfaction exceeded that predicted by ASHRAE Standard 55 or PMV-based ISO standards. 
Finally, Aftab et al. [43] presented an automatic HVAC control system, featuring realtime occupancy recognition, dynamic occupancy prediction, and simulation-guided model predictive control, implemented in a low-cost embedded system. This system was able to achieve more than 30\% energy saving but also the comfort level.

Despite several studies being available on comparisons of heating emitters, the analysis of the literature underlines the lack of data for Mediterranean regions but also the poorness in the monitoring investigations. Indeed, the experimental analysis are based on short periods, and the indoor parameters are monitored in a few points used for the description of the whole ambient area. Moreover, comparison of radiant and convective heating terminals has not found a general preference according to experimental and numerical results. Another critical point is that the analysis of thermal comfort with baseboard heaters is not supported by data, since the available papers are focused mainly on designs for increasing the energy efficiency.

The available researchers have not investigated the behaviors of the different systems by highlighting the effects of the heat gains that instead give an important contribution, mainly in the Mediterranean climate. Indeed, during the winter, the solar radiation, the occupants, and the equipment can contribute to create the comfort conditions also with lower set-points, and thus it is possible to implement cheap energy measures according to the type of emitters installed in the building.

Considering these issues, this paper proposes an experimental comparison during the heating period of three emitters supplied by a gas boiler in a Mediterranean climate to help designers to choose the proper system and management strategy with the dual purpose of selecting a comfortable but energy saving-oriented operating temperature. To give more detail, it is proposed to elaborate measured data for some reference days and weeks by analyzing the differences in thermal comfort conditions and local discomfort factors under the real operating conditions of a typical Mediterranean climate. The complete monitoring of the heated room is proposed thanks to several types of sensors that allow a discrete but detailed distribution of temperature to be discussed. The analysis of these data allows also a discussion of the operating regimes in term of set-point temperature control. Additionally, if long-term monitoring should be considered for complete characterization, this work can be considered the starting point for developing a deeper study on the optimization of a heating control strategy to avoid overheating, and local discomfort conditions for climates with mild winters. Indeed, with these data, a simulation model will be validated for exploring the energy saving potential on a seasonal basis.

\section{Study Proposal and Methodological Approach}

This paper focuses on the evaluation of the incidence of local heating emitters on thermal comfort on seasonal and diurnal scales.

The adopted methodological approach is based on in-field monitoring of indoor and outdoor parameters by using an experimental test-facility in a Mediterranean city. Three indoor heating emitters (fan-coil unit, radiant floor panels, radian baseboards) were compared. These systems were tested in the experimental station of the Department of Engineering of University of Sannio, located in Benevento [44].

The monitoring started in November 2017, and many data were acquired; in the following analysis, a 15-day period for continuous monitoring of the three systems was considered.

More in detail, with reference to the external environment, all main thermodynamic parameters were measured, including air temperature, relative humidity, solar radiation, IR radiation, rainfall, wind speed, and direction.

The indoor experimental set-up included a number of sensors for air temperature, relative humidity, average radiant temperature, and air speed (by including a black globe thermometer). The monitoring was done by dividing the room into four quadrants (namely, $\mathrm{S} 1$ is sector 1, S2 is sector 2, S3 is sector 3, S4 is sector 4); for each of them, the temperature and humidity sensors were positioned at 4 different heights; moreover, these sensors, that for air speed and the globe thermometer, were positioned in the center of the room. 
Data elaboration allowed us to obtain two main lines of analysis. First of all, a comparison between the three systems was proposed by analyzing the trend per minute of air temperature, mean radiant temperature, and relative humidity measured in the center of the room in two typical days. Then, the operative temperature was calculated and compared in order to verify the achievement of thermal comfort conditions in these days. Considering some hours, with monitored data of air speed, using 1 clo as winter clothing resistance and $1.1 \mathrm{~m}$ for the activity (corresponding to work office), the PMV and PPD indexes were calculated.

Moreover, considered all acquired data, the $\mathrm{tT}_{\mathrm{O}} \%$ index was calculated. It consists of percentage of time (minutes) in which the operative temperature $\left(T_{O}\right)$ is maintained within the comfort range, subdivided into some intermediate bands in order to discretize the description of the monitored values.

Furthermore, for each sector, the temperature distribution was studied with the aim of underlining if and how the chosen emission systems can to reach uniform conditions or if these are characterized by thermal stratification and local discomfort phenomena, such as the large temperature difference between ankles and head. More in detail, temperature trends at different heights were compared, and the temperature difference was calculated between the air temperature at $3.1 \mathrm{~m}\left(\mathrm{~T}_{\mathrm{a}_{\_} 3.1}\right)$ and $0.1 \mathrm{~m}\left(\mathrm{~T}_{\mathrm{a}_{0} 0.1}\right)$ for evaluating the vertical thermal uniformity: the measured air temperature in the middle of the room $\left(\mathrm{T}_{\mathrm{a}_{-} \mathrm{c}}\right)$ and that at all heights. Finally, the difference between the $1.1 \mathrm{~m}$ and the $0.1 \mathrm{~m}$ positions was calculated, since it should always be less than $3.0^{\circ} \mathrm{C}$, as previously explained with reference to local discomfort phenomena.

The last analysis concerns the value of the air temperature. In detail, for each sector, the percentage of time $\left(\mathrm{tT}_{\mathrm{a}} \%\right)$ in which the air temperature falls within intervals derived from the comfort zone for the operative temperature was evaluated (in a moderate environment, air and operative temperatures have very close values). Through the analysis of the monitored values, some preliminary considerations were presented regarding the optimal value for set-point temperature to reach the comfort conditions. This aspect is particularly interesting considering that, mainly for very insulated building and for systems with high inertia, the comfort conditions can be reached with lower values of the set-point temperature, achieving energy saving targets through the optimal management of the building-plant system.

\section{Experimental Activity: Set-Up}

The experimental analysis was conducted by means of the MATRIX-Multi Activity Test-Room for Innovating $X$ (Figure 1a), a building integrated laboratory for testing energy performance of components and systems under real weather conditions, as described by authors in [44].
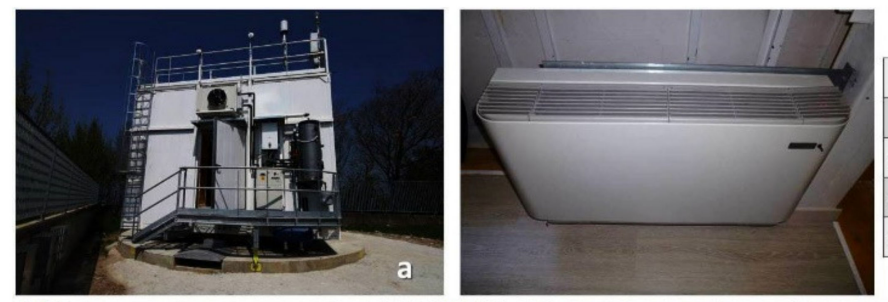

\section{b}
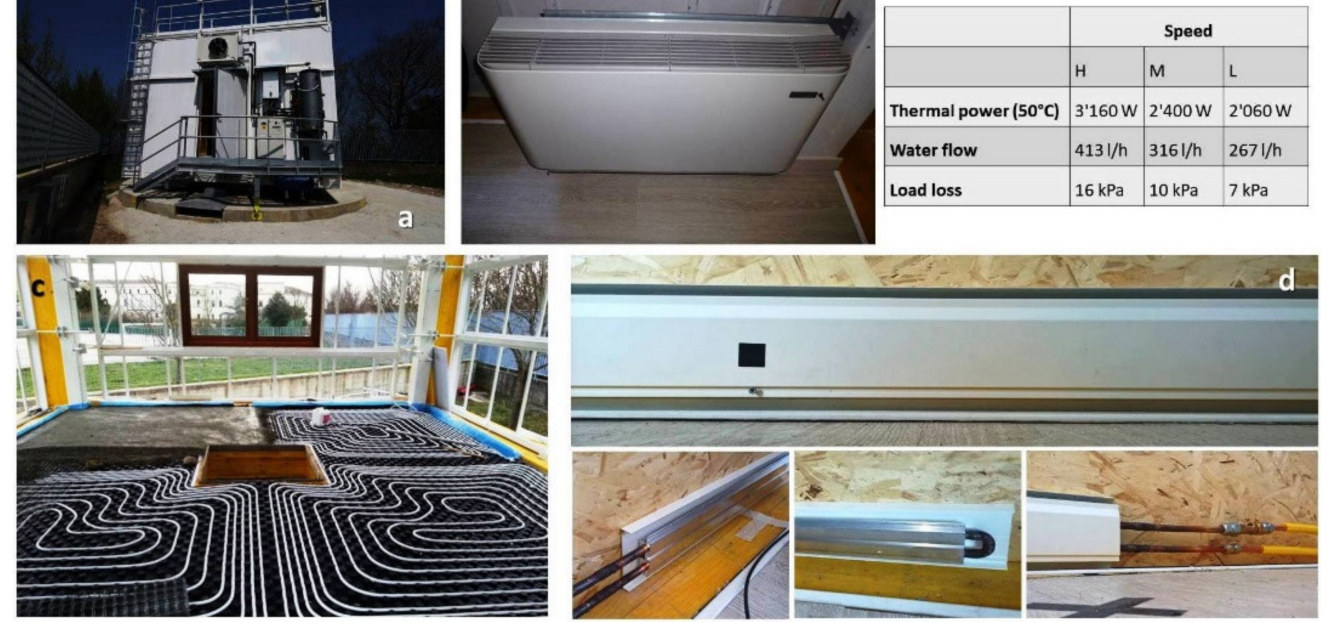

Figure 1. Experimental equipment: (a) matrix; (b) fan-coil unit; (c) radiant floor system; (d) heating baseboard. 


\subsection{Brief Description for Test-Room}

The MATRIX structure is composed of a wooden basement and roof and vertical steel frame. Three vertical walls are changeable (thicknesses between 10 and $40 \mathrm{~cm}$ ). During the monitoring, the wall package is composed by aerated cellular concrete and vacuum insulation panels, with an overall thermal transmittance of $0.40 \mathrm{~W} /\left(\mathrm{m}^{2} \mathrm{~K}\right)$. The fourth wall is mainly formed by $42 \mathrm{~cm}$ of insulation, and the overall thermal transmittance is around $0.05 \mathrm{~W} /\left(\mathrm{m}^{2} \mathrm{~K}\right)$. The window has a wood frame, with a double layer of electro-tropic glass and an air gap of $16 \mathrm{~mm}$. The overall transmittance is around $2.5 \mathrm{~W} / \mathrm{m}^{2} \mathrm{~K}$. The test cell is equipped with a condensing boiler and electric heat pump with a rated cooling capacity of $10.37 \mathrm{~kW}\left(\mathrm{EER}=4.34 \mathrm{~W}_{\mathrm{TH}} / \mathrm{W}_{\mathrm{EL}}\right)$. The hot and cold heat transfer fluids suffer an additional thermal exchange in hot and cold storage tanks, designed to allow maximum versatility of the test-cell for future developments. With reference to the heat emitters, the MATRIX is equipped with three devices in order to study different thermo-hygrometer configurations. Thus, there are two fan-coils (FCXI ACT) provided with inverter of the tangential fan and electronic thermostat. The three-speed ventilation can be controlled either manually or automatically. Figure $1 \mathrm{~b}$ shows the thermal power, the water rate, and the losses of each fan speed.

Above the intrados of the floor (with $42 \mathrm{~cm}$ of polyurethane foam from the ground), an insulating panel with preformed design and the presence of joints and knuckles was used to simplify distribution of the pipes. Four separated circuits were installed (Figure 1c), powered by two coplanar collectors; each circuit has length of $65 \mathrm{~m}$ for an overall size of $7 \mathrm{~m}^{2}$. The pipes are made of polyethylene with a diameter of $17 \mathrm{~mm}$, with an anti-oxygen barrier and these are distributed with a constant pitch of 50-1000 mm.

Finally, two radiative baseboards are installed (Figure 1d), one for each wall without door and window. The baseboard has made with aluminum alloy (EN AW 6060) certified according to reference standard. It was characterized experimentally by varying the flow rate and the supply temperature during the last winter. The experimental tests carried out show that the heating capacity $(\mathrm{W} / \mathrm{m})$ is a linear function of the temperature difference between the supply and return water. Considering the actual operating regime (water flow of $3 \mathrm{~L} / \mathrm{m}$ ), the average heating capacity was $170 \mathrm{~W} / \mathrm{m}$.

Additionally, the flow of primary air could be modified from 0.30 to $1.00 \mathrm{ACH}$, through the use of variable centrifugal air flow fans, provided with an inverter (Ariett Habitat LL 12008), in order to test different inner conditions.

The artificial lighting was achieved by means of LED light sources, fully dimmable.

The recording of climatic data was carried out by means of the central weather station placed on the roof of the laboratory, at a height of about $7.20 \mathrm{~m}$ from the ground level. Technical specifications are summarized in Table 2.

Table 2. Technical specifications of the external climatic station.

\begin{tabular}{ccccc}
\hline Sensor & Type & Model & Range & Accuracy \\
\hline Rain Gauge & Cylindrical body of $400 \mathrm{~cm}^{3}$ & NESA-ANS- & $0 \div 300 \mathrm{~mm} / \mathrm{h}$ & $\pm 2 \%$ \\
Wind speed & PL400-N & $0 \div 60 \mathrm{~m} / \mathrm{s}$ & $\pm 2 \%$ \\
Wind direction & Ultrasonic anemometer & & $0 \div 359.9^{\circ}$ & $\pm 22^{\circ} \mathrm{RMSE} 1.0 \mathrm{~m} / \mathrm{s}$ \\
Air temperature & Pt100 & DELTA OHM & $-40 \div 60^{\circ} \mathrm{C}$ & $\pm 0.1 \%$ \\
Relative humidity & Capacitive transducer & HD52.3D & $0 \div 100 \%$ & $\pm 1.5 \% \mathrm{RH}$ at $15 \div 35{ }^{\circ} \mathrm{C}$ \\
Atmospheric pressure & Piezoresistive transducer & & $600 \div 1100 \mathrm{hPa}$ & $\pm 0.5 \mathrm{hPa}$ at $20^{\circ} \mathrm{C}$ \\
Global solar radiation & Class II thermopile pyranometer & & $0 \div 2000 \mathrm{~W} / \mathrm{m}^{2}$ & $<10^{2}$ day ${ }^{-1}$ \\
\hline
\end{tabular}

\subsection{Set-Up of Experimental Equipment}

Baseboards were installed during the spring 2017; thus, the compared measurements refer to the winter 2017-2018. During the monitoring period, the operation of heating emitters was alternated with continuous monitoring as in the following schedule:

- 21 December 2017-03 January 2018 with baseboard heating;

- 20 January 2018-02 February 2018 with fan-coil units; 
- 03 January 2018-16 February 2018 with radiant heating floor.

To carry out the measurement campaign, the test-room was divided into four areas (about $9 \mathrm{~m}^{2}$ ), and in each one, air temperature and relative humidity sensors were installed at different heights: ankles $(0.1 \mathrm{~m})$, head $(1.1 \mathrm{~m})$ for a man sitting for a typical office work, and $2.1 \mathrm{~m}$ and 3.1 as representative points of thermal stratifications. The 16 sensors (Pt100 platinum thermo-resistance) were of two different types, comparable in terms of technical specifications as shown in Table 3. In more detail, at heights of $1.1 \mathrm{~m}$ and $2.1 \mathrm{~m}$, sensors produced by NESA were used, and TESTO devices were used at $0.1 \mathrm{~m}$ and $3.1 \mathrm{~m}$.

Table 3. Technical specifications of the inner sensors.

\begin{tabular}{|c|c|c|c|c|}
\hline Measure & Sensor & Range & Accuracy & Response Time \\
\hline Temperature & PT-100 NESA & $-40 \div 80^{\circ} \mathrm{C}$ & $0.015^{\circ} \mathrm{C}$ & $<60 \mathrm{~s}$ \\
\hline Relative humidity & PT-100 NESA & $0 \div 100 \%$ & $0.1 \%$ & $<60 \mathrm{~s}$ \\
\hline Temperature & PT-100 TESTO & $-20 \div 70{ }^{\circ} \mathrm{C}$ & $0.1^{\circ} \mathrm{C}$ & $<60 \mathrm{~s}$ \\
\hline Relative humidity & PT-100 TESTO & $0 \div 100 \%$ & $0.1 \%$ & $<60 \mathrm{~s}$ \\
\hline Surface temperature & Thin-flowmeter & $\geq 205^{\circ} \mathrm{C}$ & $\pm 0.8^{\circ} \mathrm{C}$ & $0.20 \mathrm{~s}$ \\
\hline Air speed & Anemometer & $0 . \overline{1}-30 \mathrm{~m} / \mathrm{s}$ & $0.1 \mathrm{~m} / \mathrm{s}$ & $<60 \mathrm{~s}$ \\
\hline Mean radiant temperature & Globe thermometer & $-40 \div+60^{\circ} \mathrm{C}$ & $0.01^{\circ} \mathrm{C}$ & $<10 \mathrm{~s}$ \\
\hline
\end{tabular}

At the room center, a globe thermometer (emission equal to 0.95 and diameter of $15 \mathrm{~cm})$ is positioned and also an air temperature and relative humidity sensor $(1.1 \mathrm{~m})$ and the anemometer. Technical details are reported in Table 3. The measurement of global temperature and knowing the air temperature allowed us to obtain the mean radiant temperature starting from a non-linear equation.

On the floor, 5 thin-film flowmeters were positioned in correspondence with air temperature sensors; these were used for recording surface temperature when the radiant system was turned on ( $\mathrm{T}_{\mathrm{S}_{-} \text {floor }}$ in the following).

During the monitoring period, the primary air flow rate was set to $0.30 \mathrm{ACH}$.

All the sensors were connected to a cr3000 data acquisition unit, and these were shielded from direct radiation coming from the window. For all internal and external devices, the sampling time was set to $1 \mathrm{~min}$.

\section{Results}

\subsection{Comfort Conditions Analysis}

The first analysis concerns the comparison of indoor thermal comfort through the analysis of the operative temperature, relative humidity, and air speed at the center of room. The operative temperature was calculated as the average of the mean radiant temperature and the air temperature.

\subsubsection{Monitoring for Selected Winter Days}

Firstly, a daily comparison was made considering comparable external climatic conditions. The selected days were 1 January with baseboards, 1 February with fan-coil units, and 7th February for floor radiant panels. Table 4 shows the main parameters useful to describe the monitored external conditions.

Table 4. Climatic data for reference days.

\begin{tabular}{cccccccccc}
\hline & \multicolumn{3}{c}{ 1 January } & \multicolumn{3}{c}{ 1 February } & \multicolumn{3}{c}{ 7 February } \\
\hline & Max & Min & Mean & Max & Min & Mean & Max & Min & Mean \\
Temperature $\left({ }^{\circ} \mathrm{C}\right)$ & 14.8 & 5.1 & 9.8 & 14.5 & 5.7 & 9.9 & 14.5 & 4.1 & 8.5 \\
Global solar radiation $\left(\mathrm{W} / \mathrm{m}^{2}\right)$ & 602 & 12 & 220 & 583 & 10 & 218 & 750 & 25 & 208 \\
Relative humidity $(\%)$ & 100 & 59 & 79.2 & 100 & 58 & 81,5 & 99 & 49 & 80.5 \\
\hline
\end{tabular}

Figure 2 reports the trends of the outdoor $\left(\mathrm{T}_{\text {ext }}\right)$ and indoor air temperature $\left(\mathrm{T}_{\mathrm{a}_{\mathrm{C}} \mathrm{c}}\right)$ and the mean radiant temperature $\left(T_{r}\right)$ recorded by the sensors in the center of the room. 

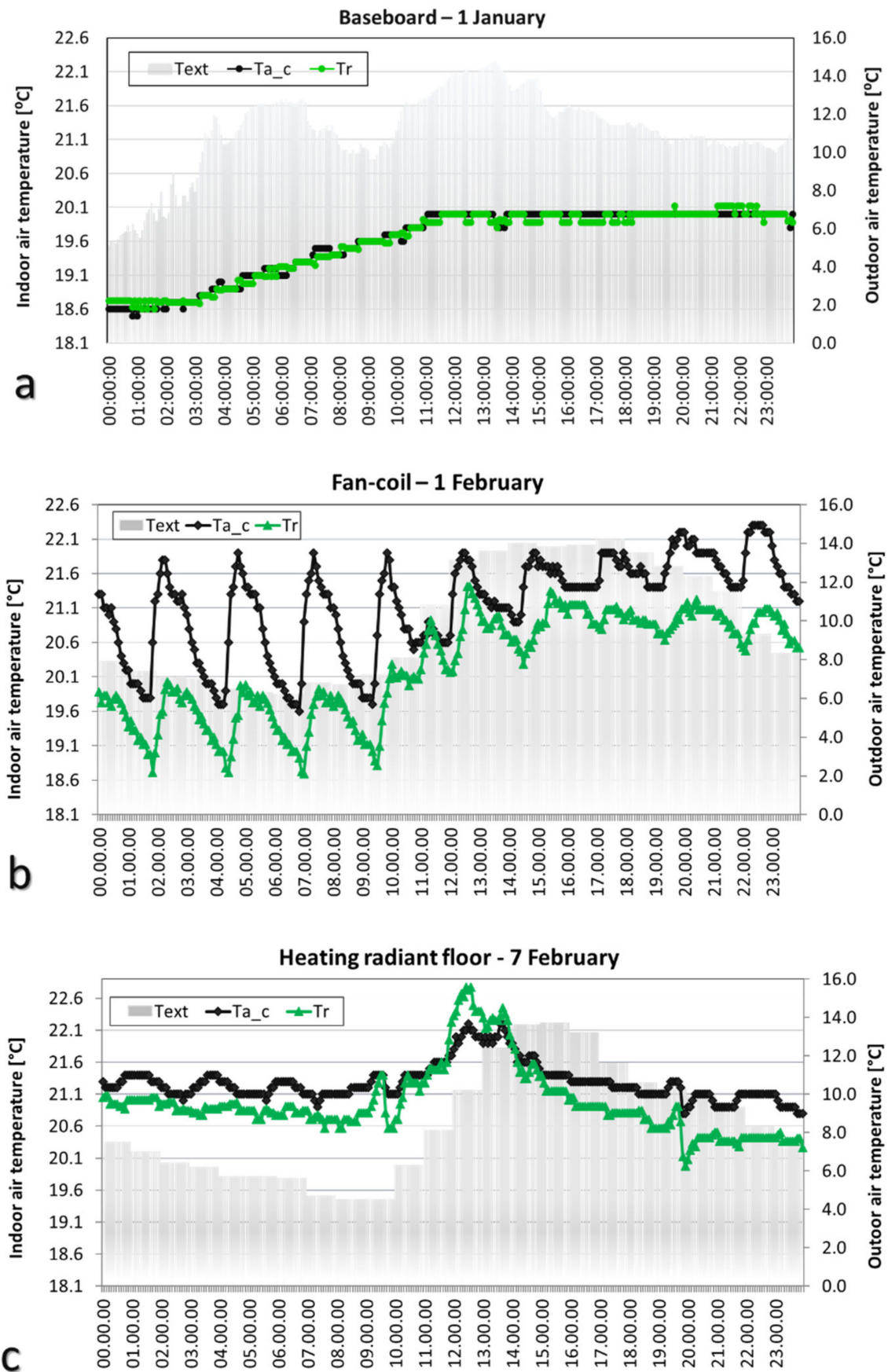

Figure 2. Recorded temperatures in the center of room: (a) baseboards; (b) fan-coil units; (c) radiant heating floor.

With the radiant floor and the baseboard system, the two profiles were almost stackable. In case of baseboards, since these were mounted near the walls, the radiative heat exchange increased and thus $T_{r}$ was close to the indoor air with an average daily difference of $0.01{ }^{\circ} \mathrm{C}$ and a maximum difference of $0.25^{\circ} \mathrm{C}$ at 7:10. When the radiant floor was considered, an average daily difference of $0.31^{\circ} \mathrm{C}$ was recorded, while the maximum difference was $0.82{ }^{\circ} \mathrm{C}$; it occurred during the late afternoon. On the other hand, the radiant temperature was higher (maximum deviation of $0.67^{\circ} \mathrm{C}$ ) than $\mathrm{T}_{\mathrm{a}_{-} \mathrm{c}}$ during the early afternoon when the combined effect of the solar radiation and floor temperature contributed to heat the building envelope. Additionally, in this case the monitored trend allowed us to highlight the different operating principle of the compared systems. The values of surface temperatures recorded on the floor also suggested uniform conditions when the radiative 
floor was operating. More in detail, considering the five available sensors, the average daily $\mathrm{T}_{\mathrm{s}_{-} \text {floor }}$ varied between $20^{\circ} \mathrm{C}$ and $21^{\circ} \mathrm{C}$. The highest value was $22.8^{\circ} \mathrm{C}$ and it was recorded at 12:20 when there was thus an important contribution of solar radiation. This was in agreement with the trend of $\mathrm{T}_{\mathrm{a}_{-} \mathrm{c}}$ and $\mathrm{T}_{\mathrm{r}}$ proposed in Figure $2 \mathrm{c}$.

Considering the calculated value of operative temperature, starting from the measurements of the black globe in the room center, it ranged between $18.6^{\circ} \mathrm{C}$ and $20.1^{\circ} \mathrm{C}$ when the baseboards were active, with an average daily value of $19.6^{\circ} \mathrm{C}$, which did not match with the comfort requirements. The relative humidity varied between $43 \%$ and $53 \%$. As shown in Figure 3, the calculated values of PMV and PPD for typical working hours in a public office were outside the comfort range with a percentage of dissatisfied people from $12 \%$ to $24 \%$. The calculation was done considering the measurements of air speed during the selected day.

1 January (baseboards)
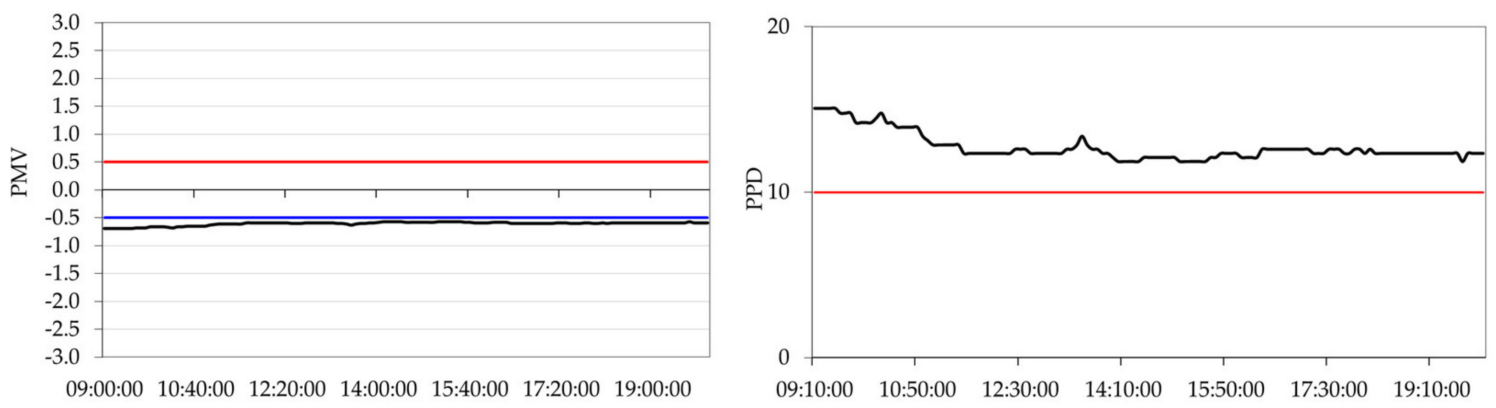

Figure 3. PMV and PPD calculation: baseboards.

With fan-coils turned on, the operative temperature varied between $19.3{ }^{\circ} \mathrm{C}$ and $21.7^{\circ} \mathrm{C}$ with an average daily value of $20.7^{\circ} \mathrm{C}$; thus, it was included in the comfort zone. The relative humidity varied between $36 \%$ and $40 \%$, with an average daily value of $40 \%$. According to Figure 4, the value of the predicted mean vote was always near the lower limit, but the percentage of dissatisfied people was under 10\% starting from the early afternoon.
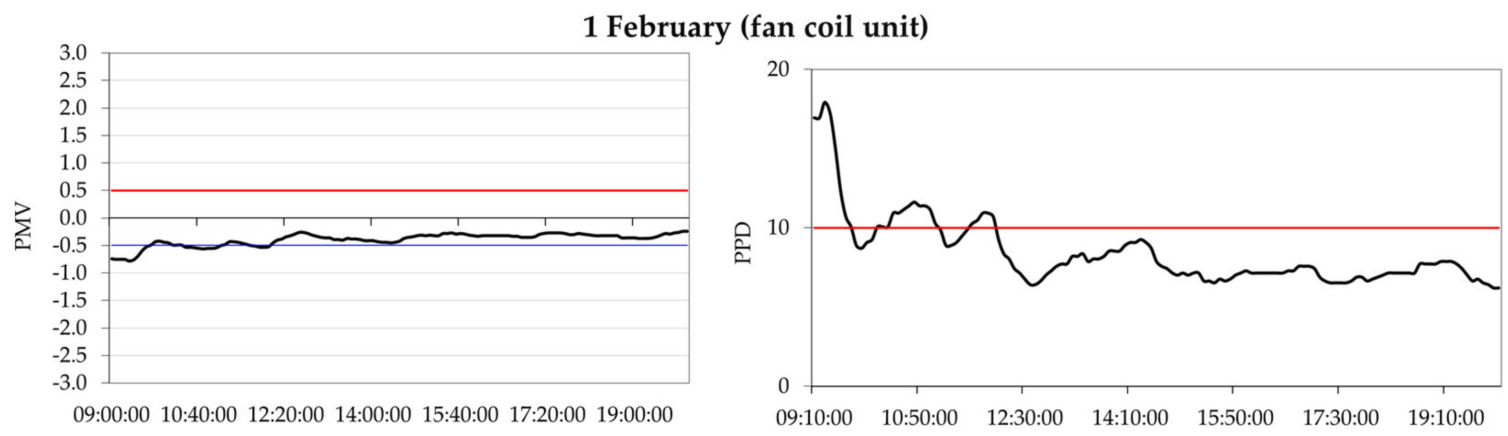

Figure 4. PMV and PPD calculation: fan coil units.

Figure 5 indicates the major attitude of the radiant system to maintain more stationary conditions. The neutral point was very close during the late morning and afternoon; instead, starting from 20:00, the PMV values tended to -0.5 also if the temperature was near $21{ }^{\circ} \mathrm{C}$ with a low level of relative humidity (35-37\%). In this case, the operative temperature was varied between $20.4^{\circ} \mathrm{C}$ and $22.5^{\circ} \mathrm{C}$, and the average daily value was $21.1^{\circ} \mathrm{C}$, while the average daily relative humidity was $39 \%$.

It has to be underlined that the floor heating usually has different comfort effects on the human body when compared to convective systems, because it has stronger effects on lower body parts, while the fan coil unit creates a layer of conditioned air around the body. Therefore, it would be not accurate to compare the two systems and their effect on 
the comfort level based on the operative temperature. However, the measured value of floor surface temperature suggests that for the available test-room, the radiant asymmetry is always under the threshold value. For example, the widely used $\Delta t_{p r}$ represents the asymmetry of a radiant field by referring to the difference between the plane radiant temperature of the two opposite sides of a small plane element [45], typically $0.6 \mathrm{~m}$ above the floor. Additionally, if this measure is not available, the measures at $0.1 \mathrm{~m}$ and $1.1 \mathrm{~m}$ that are shown in the next section indicate that there is not vertical and horizontal asymmetry for the designed system. Moreover, the current floor surface temperature requirement $\left(T_{f}\right.$ in Table 2) based on the comfortable contacting temperature is always respected. Indeed, it is believed that an excessively hot floor will lead to local thermal discomfort complaints [46].
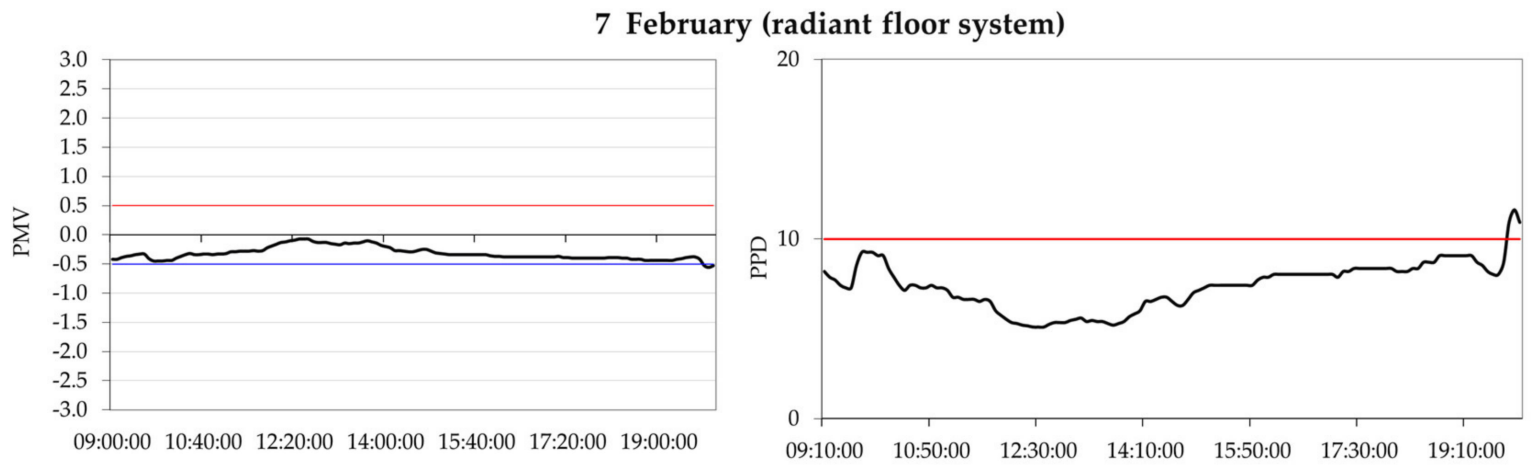

Figure 5. PMV and PPD calculation: radiant floor system.

However, further investigations will be done for evaluating different time exposures, the asymmetric-satisfaction requirement.

Finally, it can be concluded that only the fan-coil units and the radiant floor system are able to assure comfort conditions if the air temperature is also frequently higher than $20^{\circ} \mathrm{C}$, which corresponds to the set point value. The low value of relative humidity influences, in all analyzed cases, the calculated comfort indexes.

\subsubsection{Operative Temperature and Relative Humidity Analysis}

The comfort range for operative temperature $\left(19-23.5^{\circ} \mathrm{C}\right)$ was divided into several intermediate bands in order to discretize the analysis of monitored data in the room center. The Figure 6 shows the percentage of time in which the calculated value (starting from monitored air temperature and radiant temperature) falls within these ranges, considering the whole monitoring period for the three systems.

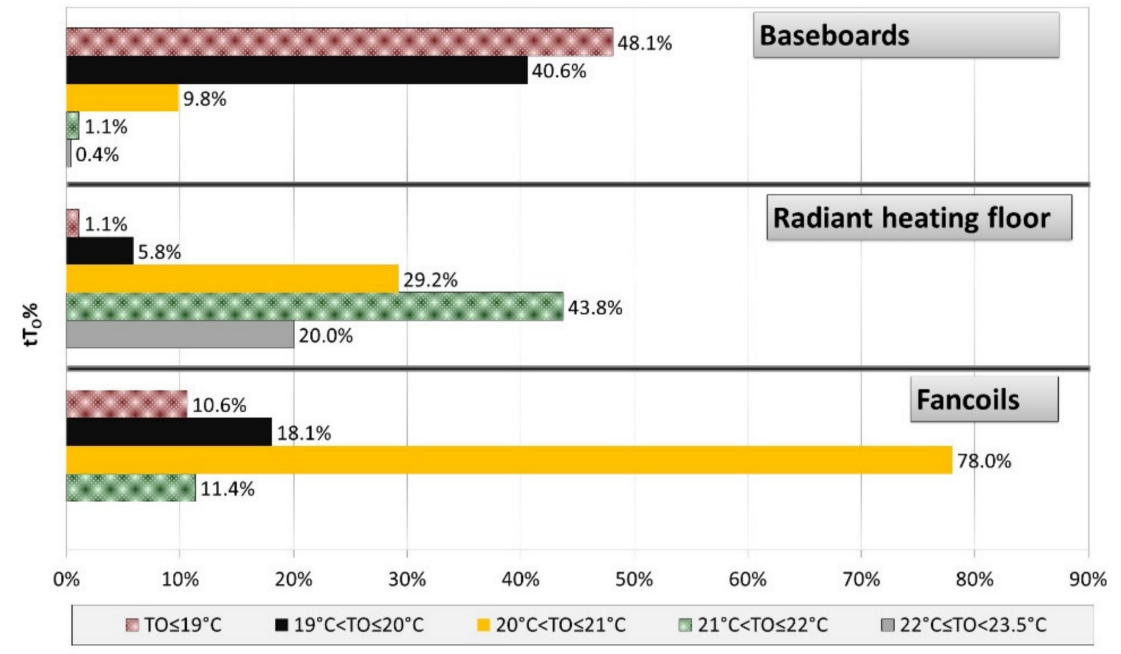

Figure 6. Percentage of time in comfort range for all systems-operative temperatures. 
Furthermore, from these data, it is clear that operative temperature was within the comfort range almost entirely throughout the considered period; it was lower than $19.5^{\circ} \mathrm{C}$ only for $1.0 \%$ of the acquisition period in the case of the radiant floor, and $11 \%$ when the fan-coils were switched on. The opposite situation occurred in the case of baseboards, since the operative temperature was lower than $19.5{ }^{\circ} \mathrm{C}$ for around $48 \%$ of the monitored values. This indicates that the baseboards needed more time to reach the set-point values and were more prone to a temperature decay during the day.

In addition, it is evident that while with the fan-coils the operative temperature was positioned for $78 \%$ of the time between $20^{\circ} \mathrm{C}$ and $21^{\circ} \mathrm{C}$, with the radiant floor, around $64 \%$ of the measures were characterized by values higher than $21^{\circ} \mathrm{C}$. This analysis allowed us to conclude that for this system, a lower set-point temperature could be used with consequent energy savings, assuring, at the same time, the comfort zone.

With reference to relative humidity values, with fan-coils, it was found that it was less than $40 \%$ (generally between $37 \%$ and $39 \%$ ) $88 \%$ of the time, and, globally, it was always lower than $50 \%$. In the case of the radiant system, the relative humidity was lower than $40 \%$ for $58 \%$ of the monitoring period, and during the remaining period, it was still lower than $50 \%$ of the period. When the baseboards were active, the relative humidity varied between $40 \%$ and $50 \%$ only for $38 \%$ of the time, and it was lower than $40 \%$ for $58 \%$ of the monitored values.

In all cases, it is clear that the emitters were not able, for their characteristics, to control the latent load.

\subsection{Air Temperature Distribution}

The second part of the proposed elaboration concerns the analysis of air temperature distribution in the four sectors individuated in the test-room, taking into consideration that fan-coils were located in the 2nd sector (right window side) and in the 4th sector (left door side). Instead, the baseboards were located on the walls without the door and the window. The same monitoring periods presented in the previous section were considered.

\subsubsection{Air Temperature Field}

Figure 7, in the case of S1 and S2, reports the trend of the air temperature monitored at different heights when the baseboards were used. In both cases, the distribution at different heights was comparable, since the temperature peaks generally correspond to the hottest hours of the day when there is also the positive contribution of solar thermal radiation. Furthermore, the greater temperature variation in both sectors was measured by the sensor at $0.1 \mathrm{~m}$; the recorded values had the greater deviation from those detected by the other sensors, while the trends of the temperature for the other heights were more uniform and regular.

Compared to the first sector, the second one was characterized by lower thermal stratification; indeed, the values at the different heights were convergent with each other.

Both figures show the temperature detected in the center of the room (height $1.1 \mathrm{~m}$ ); it can be seen that the values recorded by the sensors placed at $1.1 \mathrm{~m}$ in each sector were comparable with those measured in the central position.

More in general, in the first sector, the temperatures were higher than the corresponding temperatures of the second sector. For instance, considering the heights of $1.1 \mathrm{~m}, 2.1 \mathrm{~m}$, and $3.1 \mathrm{~m}$, the maximum temperatures were, respectively, $22.2^{\circ} \mathrm{C}, 22.5^{\circ} \mathrm{C}$, and $23.5^{\circ} \mathrm{C}$, whereas in the second sector, these values were, respectively, $21.7^{\circ} \mathrm{C}$ and $22.2^{\circ} \mathrm{C}$ (both at $2.1 \mathrm{~m}$ and $3.1 \mathrm{~m}$ ). In term of minimum values, for $\mathrm{S} 1$, the temperatures were $16.3{ }^{\circ} \mathrm{C}$, $17.6^{\circ} \mathrm{C}$, and $18.1^{\circ} \mathrm{C}$, respectively, for the heights of $1.1 \mathrm{~m}, 2,1 \mathrm{~m}$, and $3.1 \mathrm{~m}$; analogously, for S2, these were $16.6^{\circ} \mathrm{C}, 17.3^{\circ} \mathrm{C}$, and $17.5^{\circ} \mathrm{C}$. This comparison indicates that S2 was characterized by more uniform distribution, since the maximum and minimum values were almost comparable, while S1 had a more significant temperature difference, mainly between the temperature at $3.1 \mathrm{~m}$ and at $1.1 \mathrm{~m}$. 

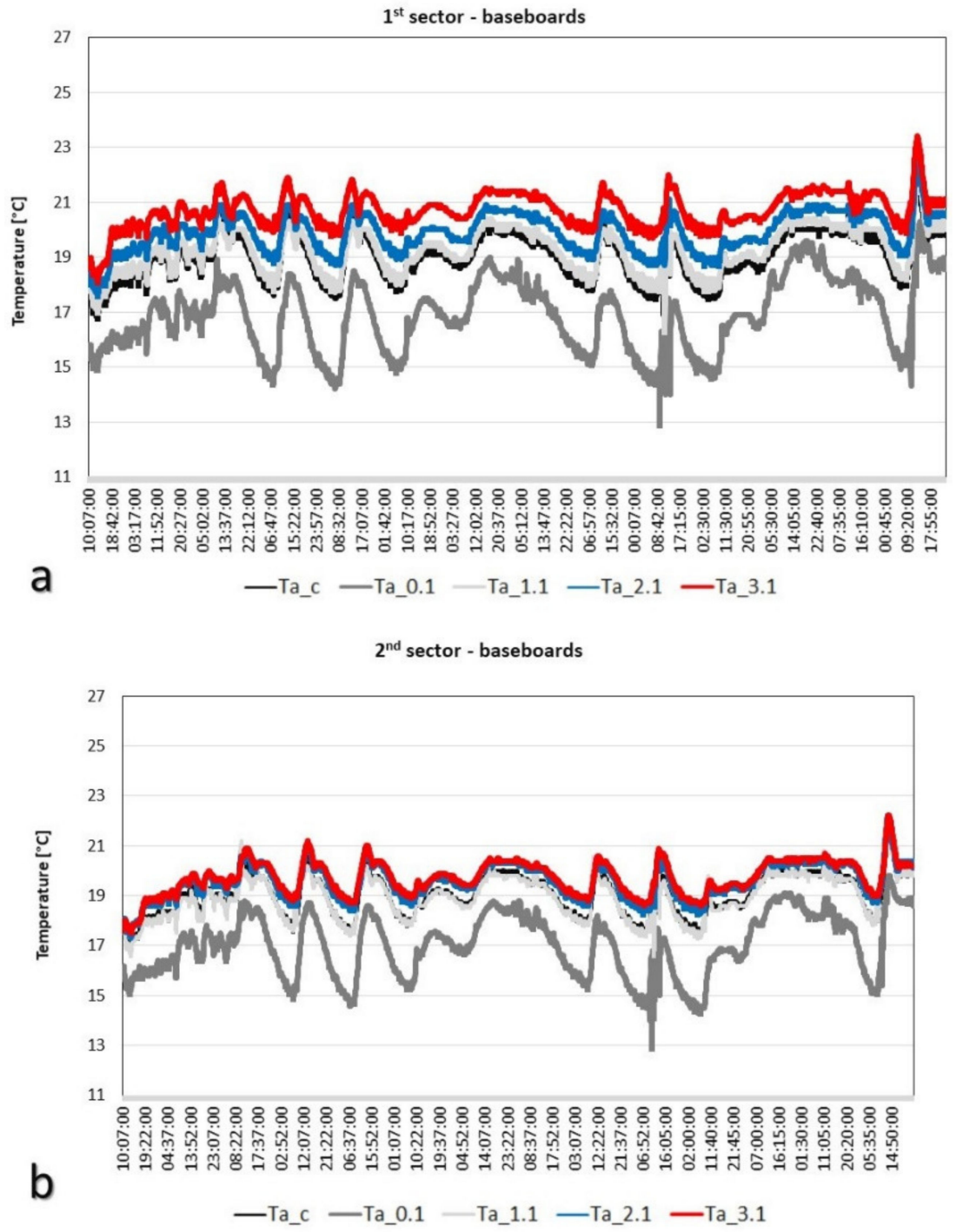

Figure 7. Air temperature at different heights with baseboards: (a) 1st sector, (b) 2nd sectors.

The sensor at $0.1 \mathrm{~m}$ was characterized by $12.9^{\circ} \mathrm{C}$ as the minimum value in both sectors, and this value was significantly lower than that monitored by the other sensors, a sign of unevenness in the distribution of the temperature at the level of occupants' ankles.

Figure $8 \mathrm{a}, \mathrm{b}$ refers to $3 \mathrm{rd}$ and 4 th sectors. Additionally, in this case the trends were

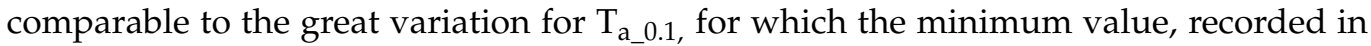
the early morning of 31 December, was around $12{ }^{\circ} \mathrm{C}$ in both sectors. The temperature monitored by the central sensor $\left(\mathrm{T}_{\mathrm{a}_{-} \mathrm{c}}\right)$ had a comparable trend with the monitored values at $1.1 \mathrm{~m}$ and $2.1 \mathrm{~m}$. The $\mathrm{S} 3$ was characterized by a more uniform distribution compared with $\mathrm{S} 4$, but the values monitored at $1.1 \mathrm{~m}$ were comparable; indeed, Ta_1.0 varied between $15.8^{\circ} \mathrm{C}$ and $22.5{ }^{\circ} \mathrm{C}$ for S3 and between $15.9{ }^{\circ} \mathrm{C}$ and $22{ }^{\circ} \mathrm{C}$ for S4. When $\mathrm{T}_{\mathrm{a} \_3.1}$ was considered, the higher values were recorded for $\mathrm{S} 4$, since it varied between $18.1^{\circ} \mathrm{C}$ and $22.8^{\circ} \mathrm{C}$.

The comparison between all sectors indicates that the higher temperatures were recorded in the first sector, probably due to the positive contribute of the solar gains during the late morning and late afternoon.

Figure 9, in the case of S1 and S2, reports the trend of the air temperature monitored at different heights when fan coil units were switched on. Data showed that, in most cases, the second sector was characterized by higher temperatures, which was due to the combined effect of solar radiation, more incident in the sector facing the window, and of the emitter position. The sensor at $3.0 \mathrm{~m}$ showed a more irregular trend, and indeed the temperature 
also reached the value of $25.1^{\circ} \mathrm{C}$, while for $\mathrm{S} 1$, the maximum value was about $22.6^{\circ} \mathrm{C}$, and it was around $20^{\circ} \mathrm{C}$ at $1.1 \mathrm{~m}$. This trend provided evidence of the phenomenon of thermal stratification caused by the heat exchange method, which was essentially convective, due to fan-coils. The temperature peaks usually correspond to the hottest hours of the day when there is also a positive contribution from solar gains.
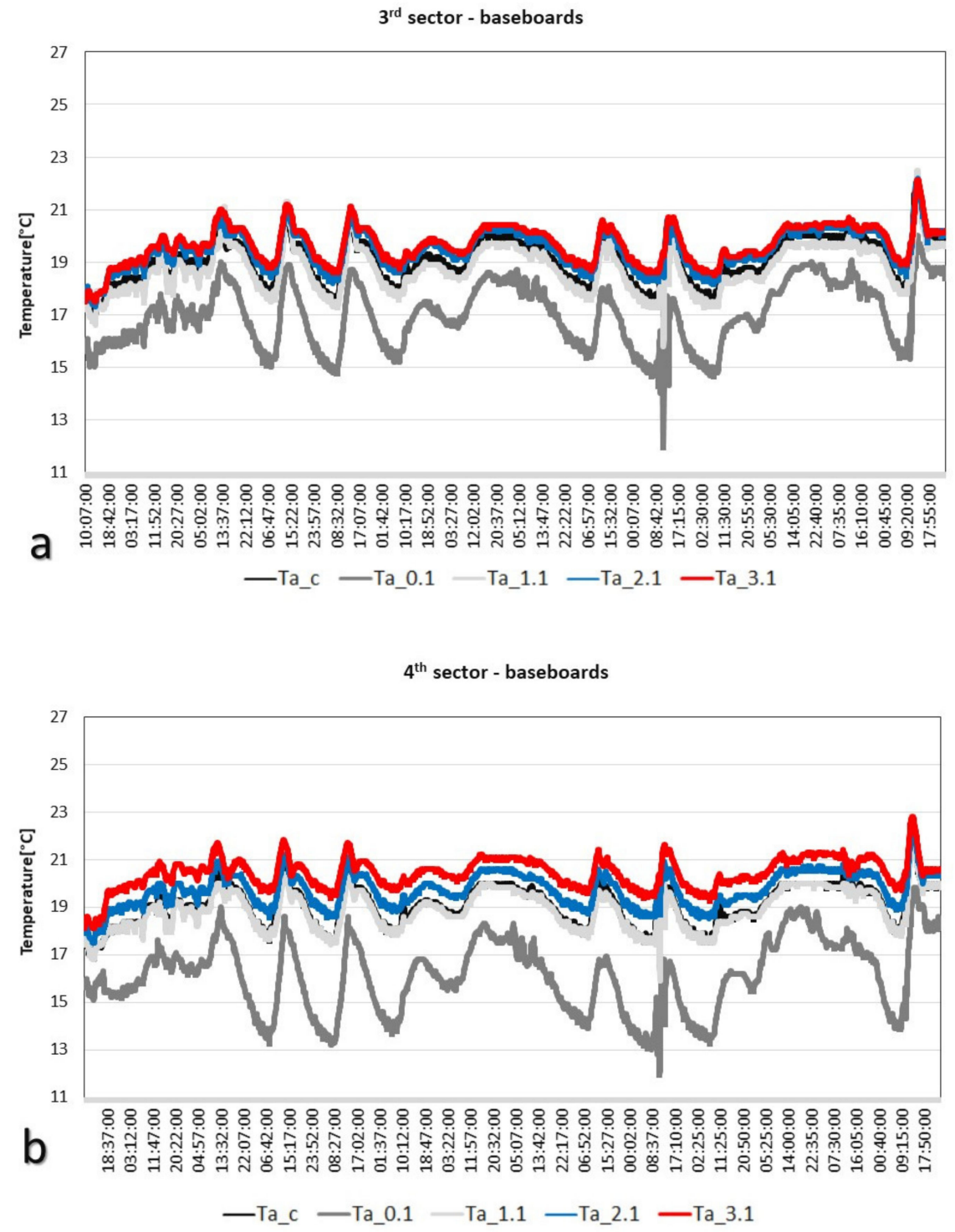

Figure 8. Air temperature at different heights with baseboards: (a) 3rd sector, (b) 4th sectors.

Figure 9 also shows the temperature monitored in the center of the room; the values recorded by sensors placed at $3.1 \mathrm{~m}$ approximated, better than the others, data recorded in the room's center for S1, since the sensor at a height of $2.1 \mathrm{~m}$ was characterized by bigger oscillations, mainly with reference to the minimum values. For the second sector, data at $2.1 \mathrm{~m}$ and $3.1 \mathrm{~m}$ were comparable with $\mathrm{T}_{\mathrm{a}_{-} \mathrm{c}}$; however, the sensor at $3.1 \mathrm{~m}$ was characterized by stronger oscillations, mainly with reference to the peak values.

Considering the extreme values for all considering periods, in both sectors, the maximum value $\left(\mathrm{T}_{\mathrm{a} \_ \text {max }}\right)$ recorded at $0.1 \mathrm{~m}$ was $20.5^{\circ} \mathrm{C}$, while the minimum $\left(\mathrm{T}_{\mathrm{a} \_ \text {min }}\right)$ was $13.3^{\circ} \mathrm{C}$ for S1 and $14.0^{\circ} \mathrm{C}$ for S2. These were significantly different from data at other heights. For instance, at $3.1 \mathrm{~m}$ and $1.1 \mathrm{~m}, \mathrm{~T}_{\mathrm{a} \_ \text {min }}$ was, respectively, 16.4 and $18.0^{\circ} \mathrm{C}$ in $\mathrm{S} 1$ and $16.4{ }^{\circ} \mathrm{C}$ and $17.2^{\circ} \mathrm{C}$ in the second sector; these measurements evidence the risk of unevenness between different heights in the same sector. 


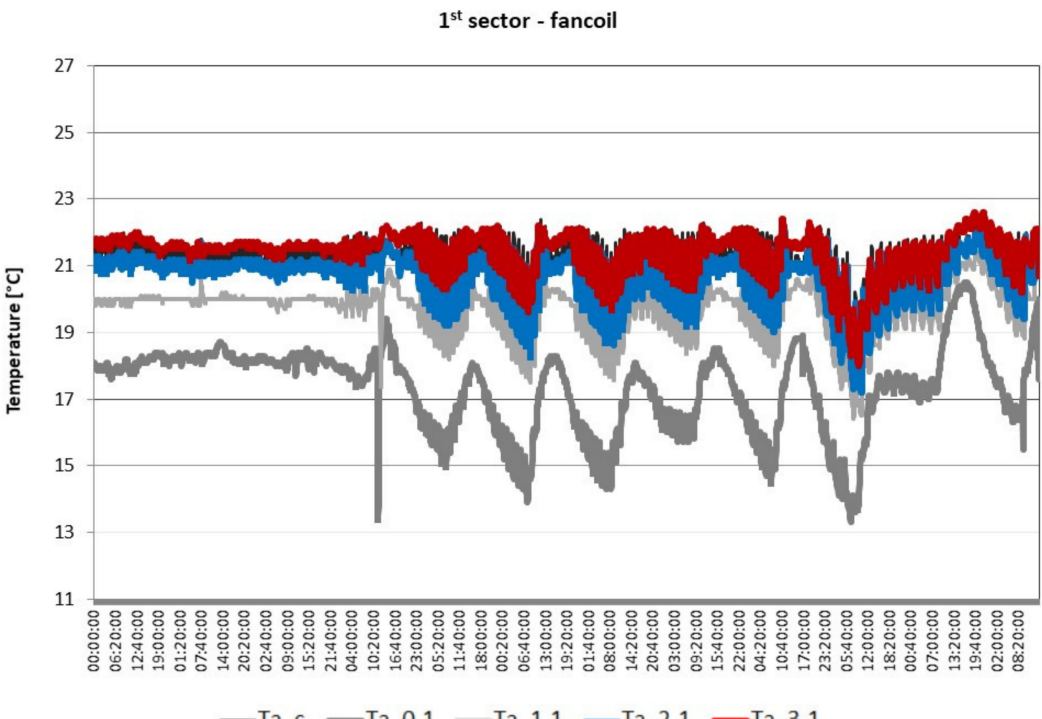

a$$
\text { -Ta_c -Ta_0.1 -Ta_1.1 -Ta_2.1 -Ta_3.1 }
$$

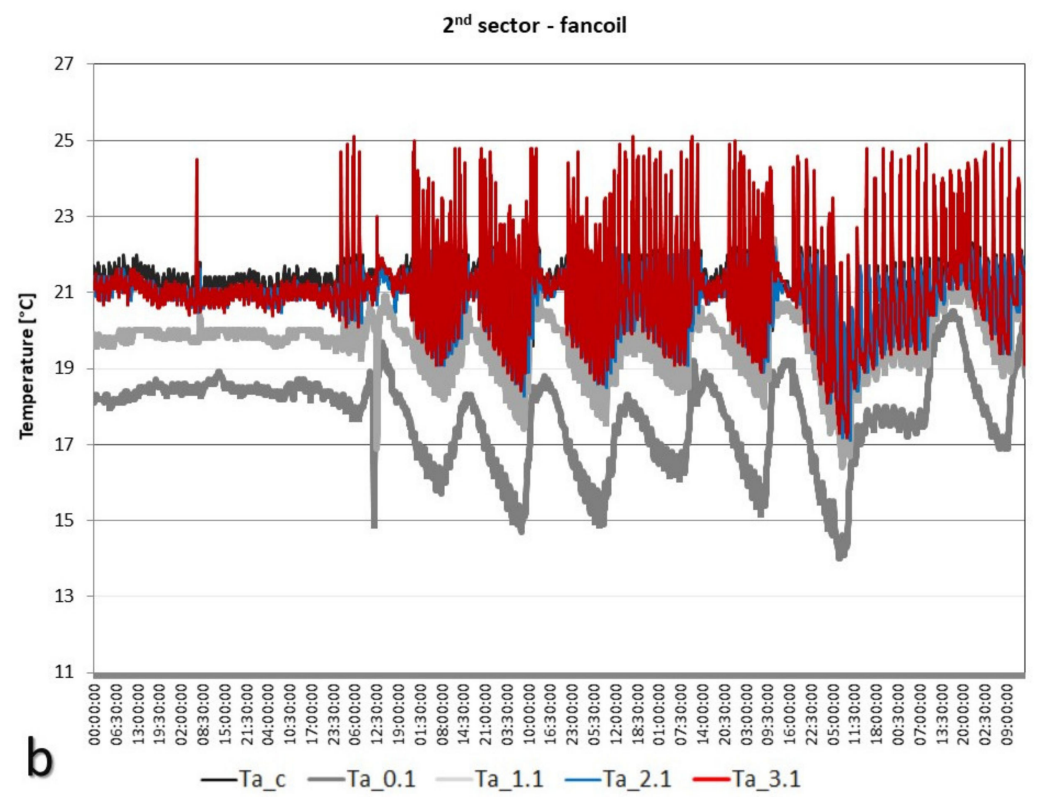

Figure 9. Air temperature at different heights with fan coil units: (a) 1st sector, (b) 2nd sector.

Figure 10 shows the air temperature trend for the third (left window side) and fourth sectors, and it is clear that these were characterized by more variable values during the day; indeed, S3 was affected by the incidence of solar radiation, while the monitoring in S4 was limited by fan coil location.

The third sector was characterized by higher temperatures compared with S4, except for the high of $3.1 \mathrm{~m}$ where the 'fan effect' was more incident due to emitter position. Considering the whole period, $\mathrm{T}_{\mathrm{a}_{-} \max }$ at $3.0 \mathrm{~m}$ was $22.7^{\circ} \mathrm{C}$ in $\mathrm{S} 3$ and $23.4^{\circ} \mathrm{C}$ in $\mathrm{S} 4$. On the contrary, in the fourth sector, the sensor at $0.1 \mathrm{~m}$ recorded the lowest value, since $\mathrm{T}_{\mathrm{a} \_ \text {min }}$ for the reference period was $11.9^{\circ} \mathrm{C}$, while it was $14.6^{\circ} \mathrm{C}$ for S3; at any time, the difference between the monitored temperature at $0.1 \mathrm{~m}$ and other heights was much more evident. The temperature profile that corresponded to the height of $1.1 \mathrm{~m}$ was very similar for the analyzed quadrants, and it oscillated around an average value of $19.7^{\circ} \mathrm{C}$ and a minimum value of around $16.3^{\circ} \mathrm{C}$.

Considering S3 and the sensors located at $2.0 \mathrm{~m}$ and $3.0 \mathrm{~m}$, the trends were comparable, with a mean value $\left(\mathrm{T}_{\text {a_mean }}\right)$ in all periods, respectively, of $20.7^{\circ} \mathrm{C}$ and $20.9^{\circ} \mathrm{C}$; these profiles were very close to the monitored values in the middle of the room where $\mathrm{T}_{\mathrm{a} \_ \text {mean }}$ was 
$21^{\circ} \mathrm{C}$. In the fourth sector, from the data recorded at $2.0 \mathrm{~m}$ and $3.0 \mathrm{~m}$, rounding up and down, for the trend monitored at the room's center, the $\mathrm{T}_{\mathrm{a} \_ \text {mean }}$ was $19.7^{\circ} \mathrm{C}$ at $2.0 \mathrm{~m}$ and $20.7^{\circ} \mathrm{C}$ at $3.1 \mathrm{~m}$, respectively. However, there was a temperature difference at each time of around $2-3{ }^{\circ} \mathrm{C}$ with values recorded at $1.1 \mathrm{~m}$, and a greater difference of $4-5{ }^{\circ} \mathrm{C}$ with values corresponding at $0.1 \mathrm{~m}$.

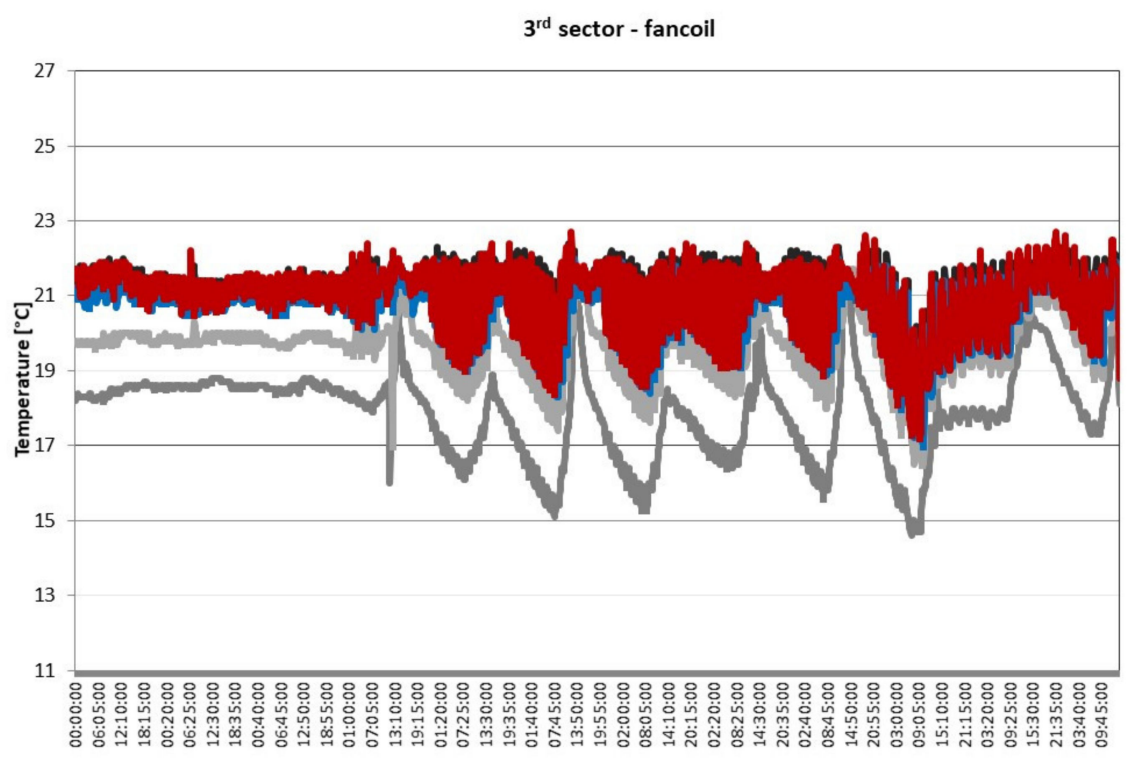

a
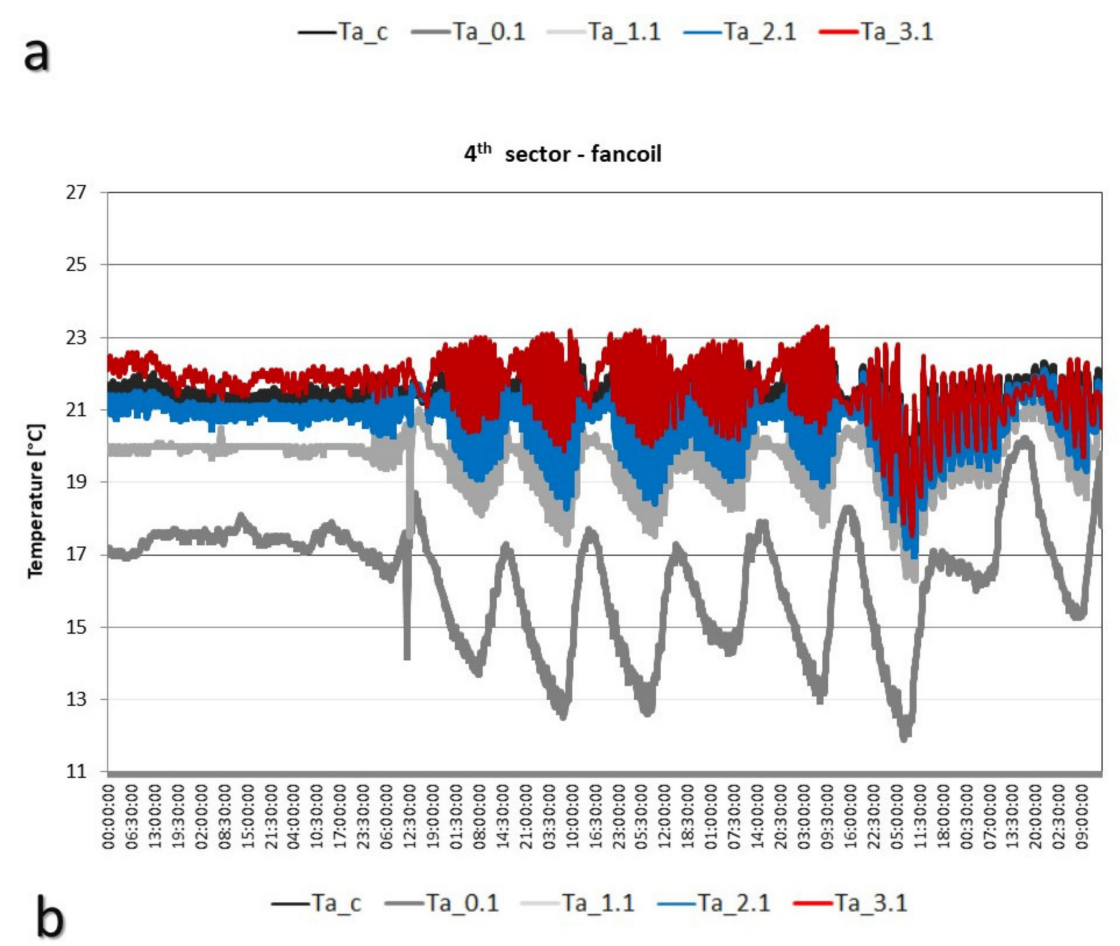

Figure 10. Air temperature at different heights with fan coil units: (a) 3rd sector, (b) 4th sector.

Comparing the four sectors, it is evident that $\mathrm{S} 2$ was characterized by the highest values. The temperature profiles relating to the same height but on different sectors were quite comparable; there was not evident horizontal asymmetry, especially at a height of $1.1 \mathrm{~m}$ and $2.1 \mathrm{~m}$. Instead, considering the position at $3.1 \mathrm{~m}$, the difference between air temperatures recorded at the same time in S1 and S2 varied between $-4.0^{\circ} \mathrm{C}$ and $+2.0^{\circ} \mathrm{C}$, and it varied from $-2.6{ }^{\circ} \mathrm{C}$ and $3.7^{\circ} \mathrm{C}$ considering sectors S2 and S4. At the height of 
$0.1 \mathrm{~m}$, the greatest variation happened between $\mathrm{S} 1$ and $\mathrm{S} 3\left(-3.6^{\circ} \mathrm{C} \div 0.3^{\circ} \mathrm{C}\right)$ while the temperature difference varied between $0.2{ }^{\circ} \mathrm{C}$ and $2.9^{\circ} \mathrm{C}$ considering sectors $\mathrm{S} 2$ and S4.

The same analysis was proposed for the radiant floor system for which also the surface temperature was shown. The monitored data for the first and second sectors are proposed, respectively, in Figure 11a,b; the profiles for the other sectors are reported in Figure 12.

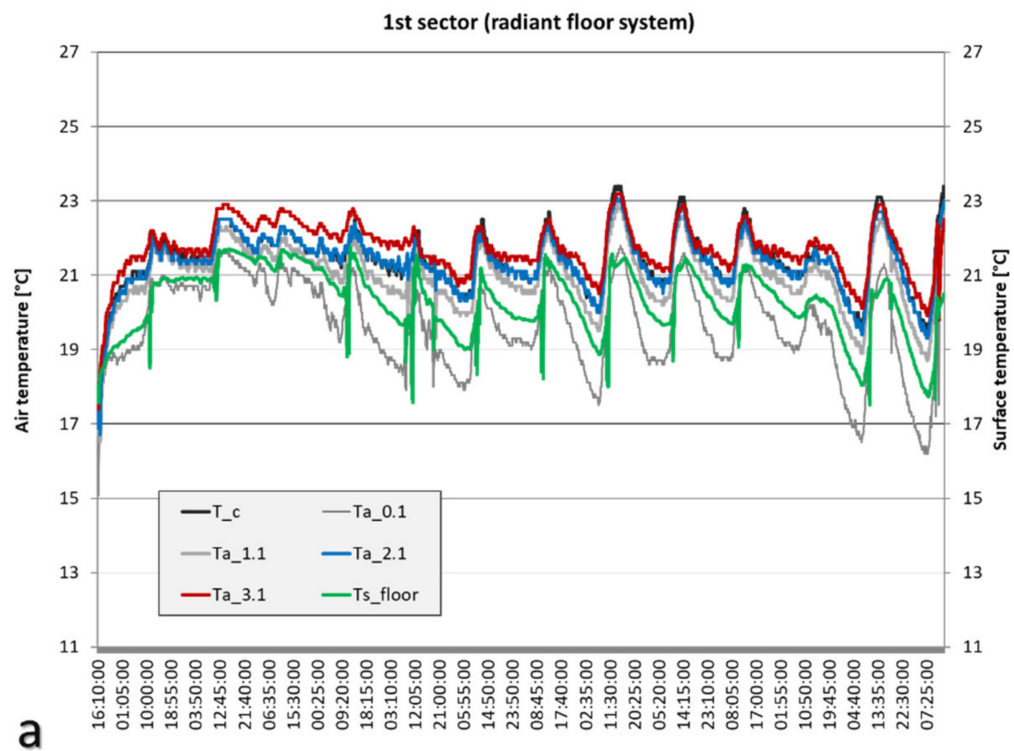

2nd sector (radiant floor system)

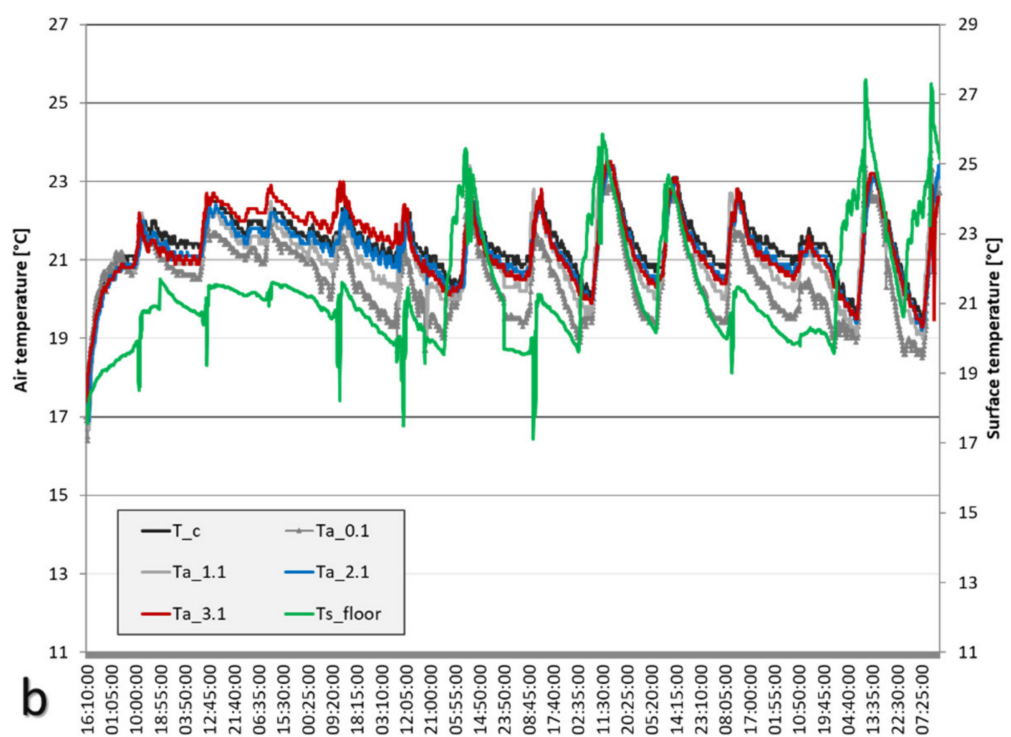

Figure 11. Air temperature at different heights with radiant floor system: (a) 1st sector, (b) 2nd sector.

In all cases, it is evident that the long start-up period of the system allowed $20^{\circ} \mathrm{C}$ to be reached in more than three hours, starting from air temperature of around $17^{\circ} \mathrm{C}$. After this transient period, the air temperature trend at $0.1 \mathrm{~m}$ was close enough to values at other heights; this phenomenon did not happen with the fan coil system, due to the different heat exchange mechanism. For each other height, air temperature values were comparable, and these were very close to data recorded by the sensor in the room center; for instance, considering the whole monitoring period in $\mathrm{S} 1, \mathrm{~T}_{\mathrm{a} \_ \text {mean }}$ was $21.0^{\circ} \mathrm{C}$ at $1.1 \mathrm{~m}$, $21.4^{\circ} \mathrm{C}$ at $2.1 \mathrm{~m}$, and at room center it was $21.7^{\circ} \mathrm{C}$ at $3.1 \mathrm{~m}$. In the second and third sectors, the mean values were around $21.2{ }^{\circ} \mathrm{C}$ at each height, and $\mathrm{T}_{\mathrm{a} \_ \text {mean }}$ was $21.5^{\circ} \mathrm{C}$ in the last considered sector. 
The higher values were $23.8^{\circ} \mathrm{C}$ in S2 and $26.4{ }^{\circ} \mathrm{C}$ in S3, and in both cases they were recorded by sensors at $0.1 \mathrm{~m}$; this was due to the combined effect of increased surface temperature and solar gains. This situation was strongly different from the operation period of the fan coil units. Moreover, the peak values recorded by the other sensors were comparable, and these did not have a large deviation for a device at $3.1 \mathrm{~m}$, unlike the fan coils. For instance, $\mathrm{T}_{\mathrm{a} \_ \text {max }}$ was around $23{ }^{\circ} \mathrm{C}$ in the first and fourth sectors, and it was around $23.5^{\circ} \mathrm{C}$ for $2 \mathrm{~S}$, while it was also $24.3^{\circ} \mathrm{C}$ in the third sector $(1.1 \mathrm{~m})$.
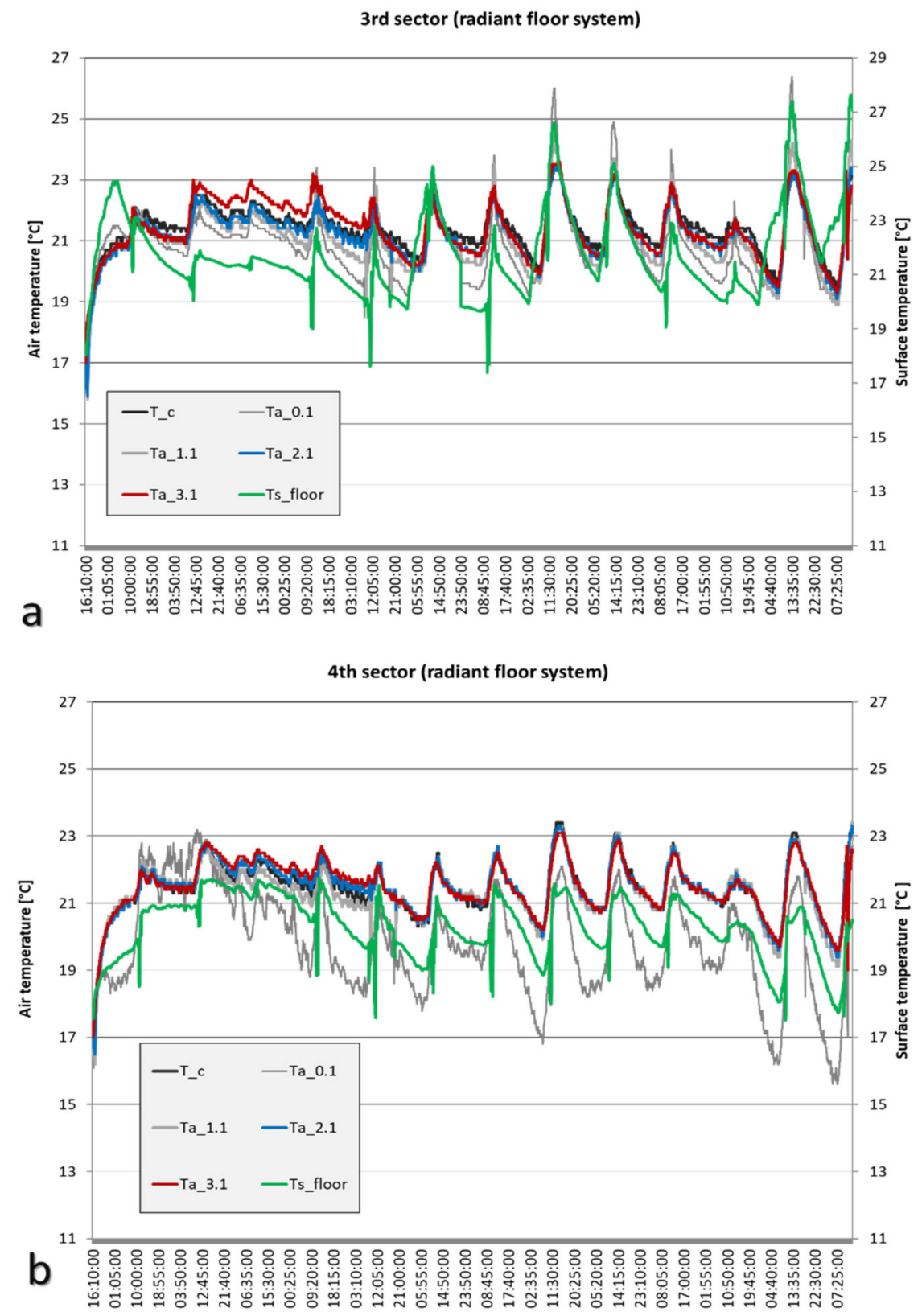

Figure 12. Air temperature at different heights with radiant floor system: (a) 3rd sector, (b) 4th sector.

It could also be observed that the surface temperature should not exceed the value of $29^{\circ} \mathrm{C}$ suggested by the standard [5]. For each sector, the recorded values were very close to the records of the sensor at $0.1 \mathrm{~m}$, and this is another aspect that underlines the uniformity of the temperature field inside the room. The switch-off was clear when there were rapid drops in temperature; the lower recorded value ranged between $17^{\circ} \mathrm{C}$ and $19{ }^{\circ} \mathrm{C}$. However, some deviations can be noted. First of all, S3 and S2 were usually characterized by the higher value of $\mathrm{T}_{\mathrm{s}_{-} \text {floor }}$. These sectors were the ones with the coils closest to the 
flow manifold, and therefore the hottest water circulates; for this reason, the temperature at ignition increased faster and to a higher value $\left(24.5^{\circ} \mathrm{C}\right)$ in S3. Moreover, during the sunniest hours, the temperature increased; for instance, in the last day of monitoring at 13:30, with an outdoor temperature of $15^{\circ} \mathrm{C}, \mathrm{T}_{\mathrm{s}_{\text {fl}}}$ loor was $27.4{ }^{\circ} \mathrm{C}$ for S2 and $27.6^{\circ} \mathrm{C}$ for S3.

The calculation of horizontal temperature difference between sensors corresponding to the same height but in different sectors showed that only the sensors located lower had greater deviations due mainly to the effect of solar irradiation from the window. This phenomenon was particularly evident between sectors 1 and 3 during the afternoon (13:00-14:00) of 15 February, with external solar radiation between 539 and $567 \mathrm{~W} / \mathrm{m}^{2}$. Indeed, in this case, the air temperature difference was $-5.5^{\circ} \mathrm{C}$. For all other heights, this difference was much limited and lower compared with the operation period of fan coils. For instance, at $1.1 \mathrm{~m}$, between S1and S2 and between S1 and S3, this difference varied from $-1.9^{\circ} \mathrm{C}$ to $0.7^{\circ} \mathrm{C}$; at $2.0 \mathrm{~m}$ considering the first and fourth sectors, it varied between $-0.4^{\circ} \mathrm{C}$ and $0.3^{\circ} \mathrm{C}$; at $3.0 \mathrm{~m}$ for S2 and S4 it varied during the monitoring period between $-1.8^{\circ} \mathrm{C}$ and $1.1^{\circ} \mathrm{C}$.

\subsubsection{Asymmetry of Air Temperature}

Another analysis concerns the comparison between vertical temperature difference with data of sensors in the same sectors and air temperature difference with data recorded in the room center. The temperature difference between data at $1.1 \mathrm{~m}$ and $0.1 \mathrm{~m}$ was calculated; it should be always lower than $3.0^{\circ} \mathrm{C}$, as previously explained with reference to local discomfort phenomena.

Figure 13, in the case of baseboards, shows the maximum, minimum, and mean values of the calculated temperature differences.

The discrete evaluation of $\Delta \mathrm{T}_{\mathrm{pr}, \mathrm{wc}}$, assumed as the difference $\mathrm{T}_{\mathrm{a} \_3.1}-\mathrm{T}_{\mathrm{a} \_0.1}$, highlights that in all sectors, the threshold value was exceeded; for instance, in the first sector, during the 30th of December, from 10:00 to 11:30 this values was higher than $6^{\circ} \mathrm{C}$, while in the other sectors it varied from $1.0^{\circ} \mathrm{C}$ to $4.5^{\circ} \mathrm{C}$ on the same day. However, for S4, the maximum difference $\left(7.4^{\circ} \mathrm{C}\right)$ was recorded at 13:30 during the same day. Considering the average value for all monitoring periods, it seems that a sensible thermal stratification occurred mainly in S1 and S4.

The temperature difference between the room center and the other sensor allowed us to estimate horizontal non-uniformity inside the room. Considering the difference with the values monitored at $1.1 \mathrm{~m}$ and $2.1 \mathrm{~m}$, both the average and extreme values were very limited. More in detail, $\mathrm{T}_{\mathrm{a}_{-} \mathrm{c}}-\mathrm{T}_{\mathrm{a} \_1.1}$ was always lower than $3{ }^{\circ} \mathrm{C}$ with a maximum value of $1.1^{\circ} \mathrm{C}$, which usually occurred after midday, and thus it was also influenced by the external conditions. Instead, the maximum difference $\mathrm{T}_{\mathrm{a}_{-} \mathrm{c}}-\mathrm{T}_{\mathrm{a} \_3.1}$ varied between $-3.2{ }^{\circ} \mathrm{C}(\mathrm{S} 3$ ) and $-4.1{ }^{\circ} \mathrm{C}(\mathrm{S} 1)$. The negative values confirmed the phenomenon of thermal stratification also when the reference was the central sensor. Finally, according to the average value, the difference $\mathrm{T}_{\mathrm{a} \_1.1}-\mathrm{T}_{\mathrm{a} \_0.1}$ was lower than $3{ }^{\circ} \mathrm{C}$, and thus the discomfort phenomenon was usually avoided. However, the extreme value of $4.9^{\circ} \mathrm{C}$ could be reached in the first and fourth sectors in both cases on 30 December, which was a sunny day.

In the case of fan-coils, Figure 14 shows that in the fourth sector, where the fancoil was located, the vertical temperature difference was very considerable; indeed, for the calculation of $\mathrm{T}_{\mathrm{a} \_3.1}-\mathrm{T}_{\mathrm{a} \_0.1}$, the maximum recorded value could reach $10{ }^{\circ} \mathrm{C}$, and the maximum value was $8.3^{\circ} \mathrm{C}$ for $\mathrm{S} 1$ and $\mathrm{S} 2$. These values indicate a possible thermal stratification phenomenon in the ceiling. Indeed, the average values, mainly in the sectors where the units were located, were also high, and this indicates that usually in the room there was a vertical temperature difference that was on the verge of overcoming the prescribed threshold.

Analyzing temperature differences between the sensor in the room center and sensors at other heights (horizontal asymmetry), it can be seen that lower values were obtained, for each sector, with the sensor at $2.1 \mathrm{~m}$. The mean values, considering data for the entire monitoring period, suggested good results also for sensors at 3.1 and $1.1 \mathrm{~m}$, also if, with 
several external conditions, very extreme temperature differences could be recorded; for instance, $\mathrm{T}_{\mathrm{c}}$ could be also $17.1 \%$ (S4) or $19.9 \%$ (S2) higher than values recorded at $1.1 \mathrm{~m}$. Moreover, $\mathrm{T}_{\mathrm{a} \_\mathrm{c}}-\mathrm{T}_{\mathrm{a} \_3.1}$ could reach $-5.6{ }^{\circ} \mathrm{C}$ around $15: 00$ on 21 January or $-5.0{ }^{\circ} \mathrm{C}$ at $6: 30$ on 1 February. This means that non-uniformity was due both to external conditions (e.g., effect of solar radiation) and position or operating mode of the fan coil units. The greatest difference could be noted between $T_{c}$ and $T_{a_{-} 0.1}$, since the mean values recorded for the whole period in the center could be higher, from $14.6 \%$ (S3) to $22.3 \%$ (S4). More in detail, in S2, during the early morning (7:30-8:30) when the fan coils started working, this difference was around $8.8 \div 9.0^{\circ} \mathrm{C}$; in the same hours, it was around $6.0^{\circ} \mathrm{C}$ in the other sectors.
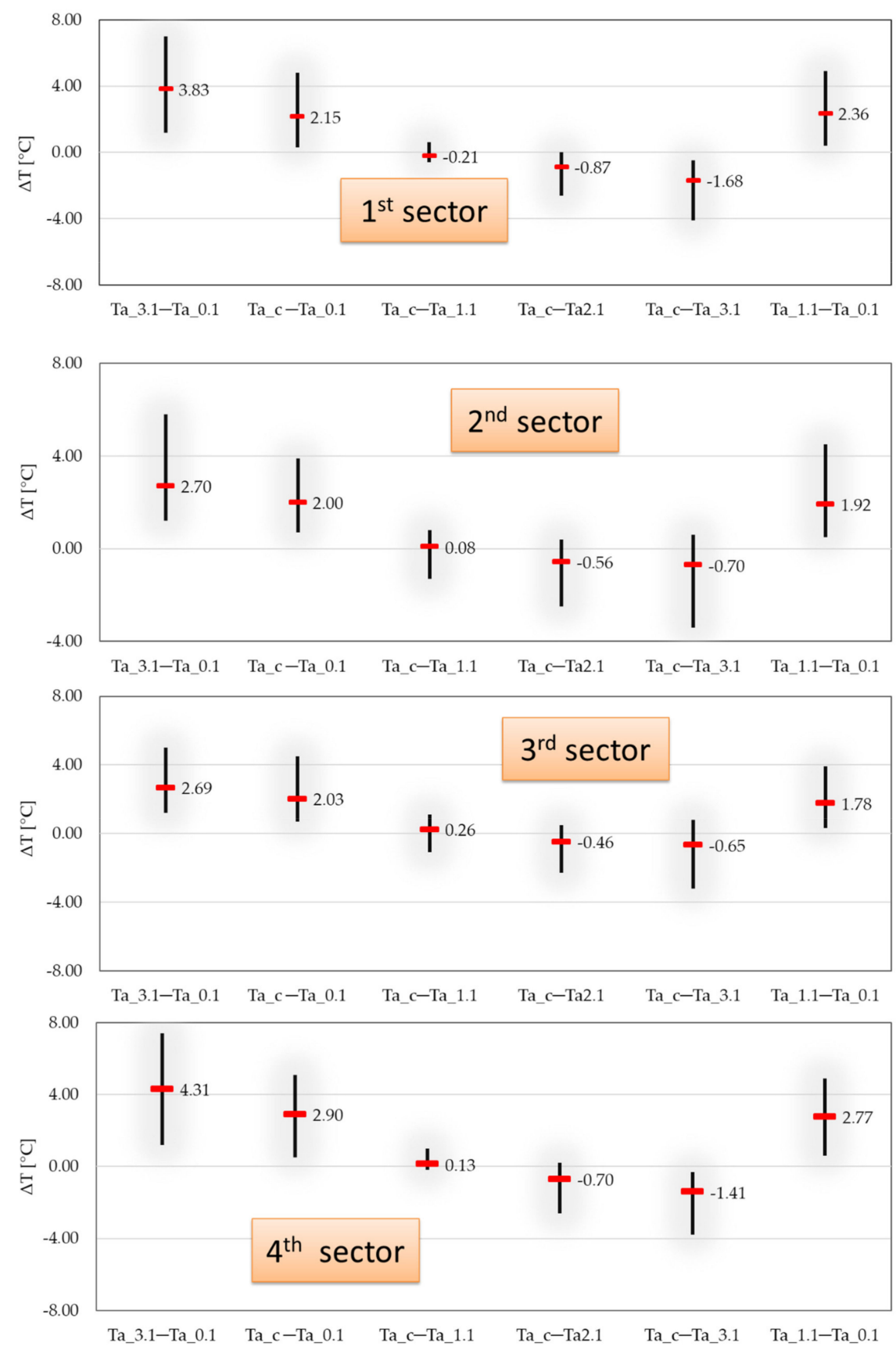

Figure 13. Extreme values for vertical temperature difference: baseboards. 

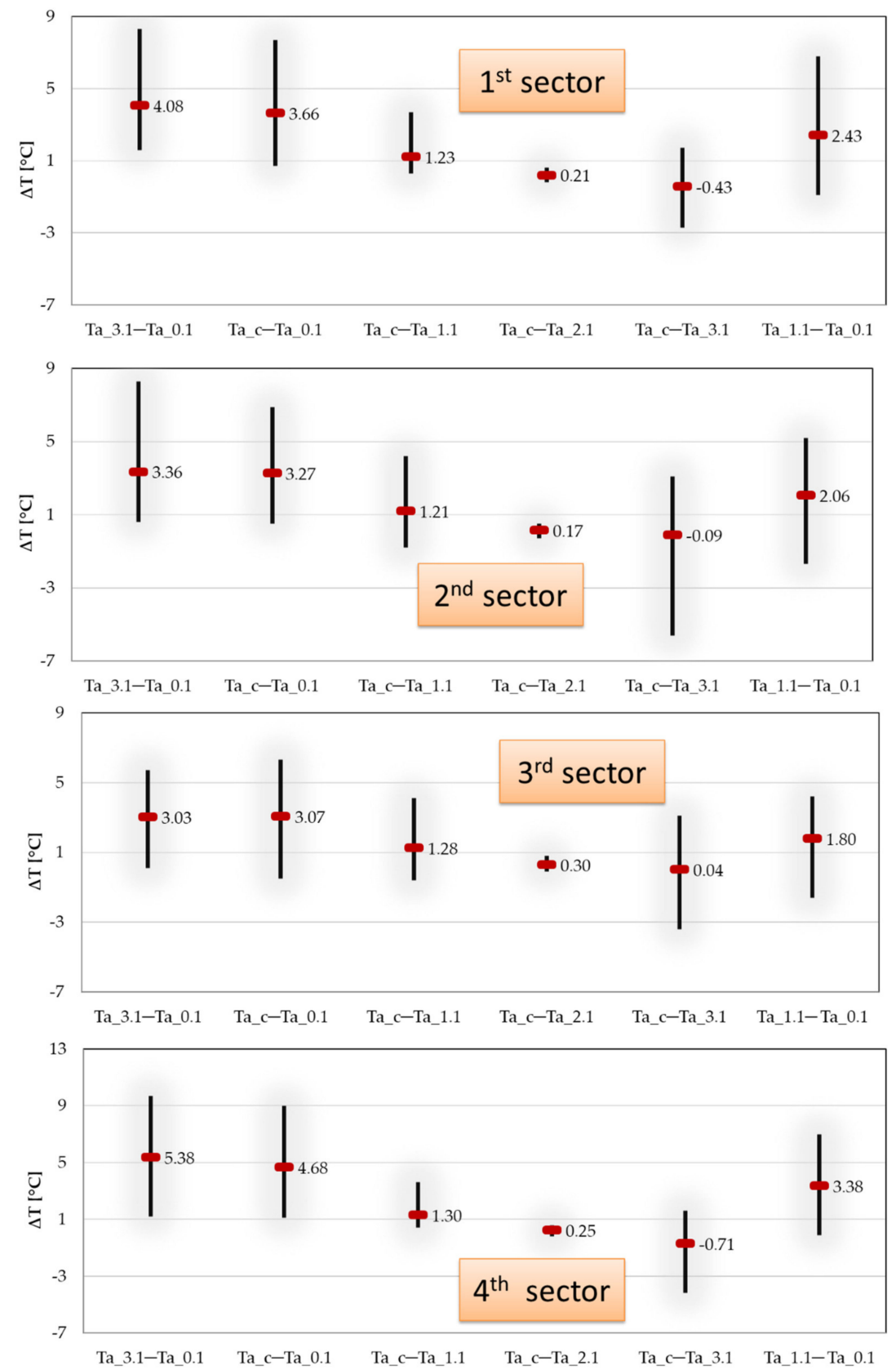

Figure 14. Extreme values for vertical temperature difference: fan coil units.

These considerations allow us to conclude that temperature distribution is very uneven, and consequently the phenomena of local discomfort can be frequent.

The same analysis was proposed with the floor radiant system (Figure 15). The lack of uniformity of horizontal temperature distribution was lower than in the case of fan coil units (between $5 \%$ and $8 \%$ ); indeed, considering the sensor at $1.1 \mathrm{~m}$ and $2.1 \mathrm{~m}$, the values of temperature difference did not exceed $+2.0{ }^{\circ} \mathrm{C}$ and were always greater than $-0.3{ }^{\circ} \mathrm{C}$. Considering sensors at $3.1 \mathrm{~m}, \mathrm{~T}_{\mathrm{c}}$ could also become around $3.0-3.5^{\circ} \mathrm{C}$ higher, and this happened at 12:00 on 16 February, one of the hottest days of the considered period.

Considering the sensor at $0.1 \mathrm{~m}$, the difference was higher (also 26-31\%), with maximum values in the 2 nd sector and 3 rd sector where $T_{c}-T_{a_{-} 0.1}$ was, respectively, $+5.7^{\circ} \mathrm{C}$ and $6.10^{\circ} \mathrm{C}$.

Even the vertical temperature distribution was more uniform, and indeed the temperature difference measured between $0.1 \mathrm{~m}$ and $3.1 \mathrm{~m}$ was smaller both on average and with reference to the maximum values with respect to fan coil units. Only during the system 
start-up some bigger differences were recorded, for instance in sector 3 and 1 it was $-4.6^{\circ} \mathrm{C}$ since when radiant floor is turned off temperature reaches $16-17^{\circ} \mathrm{C}$ at $0.1 \mathrm{~m}$.
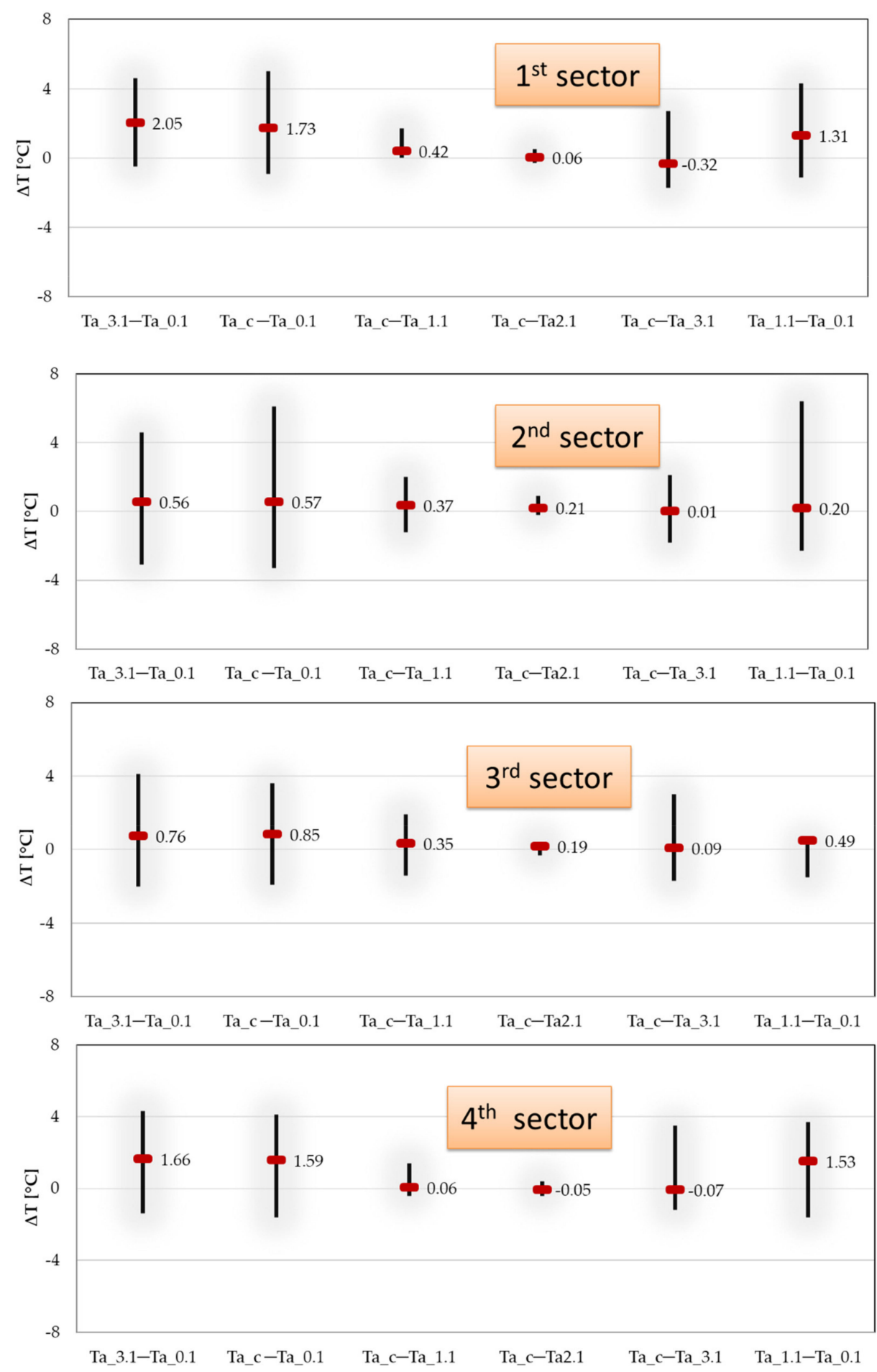

Figure 15. Extreme values for vertical temperature difference: radiant floor system.

The temperature difference for heights $1.1 \mathrm{~m}$ and $0.1 \mathrm{~m}$ was usually lower than in the previous case, and only in a few cases did it exceed the limit value $\left(3^{\circ} \mathrm{C}\right)$. More in detail, it happened only on 16 February around 12:00 when the effect of solar gains tended to locally heat the place where the sensor was placed; extreme values were recorded in the 3rd sector $(+6.40)$ and in the 1 st sector $\left(+4.30^{\circ} \mathrm{C}\right)$. For all other days, this difference varied between $0.2^{\circ} \mathrm{C}$ and $1.5^{\circ} \mathrm{C}$. 


\section{Discussion}

Monitoring results suggest that for the heating season, the radiant floor system allows better performance in term of thermal comfort and temperature distribution. All available data indicate another interesting consideration regarding air temperature value, taking into account that set point temperature, during the experiment, was fixed to $20^{\circ} \mathrm{C}$, as the normative for public buildings imposed in many countries.

More in detail, assuming that for moderate environments the air temperature is a good approximation of the operative temperature, the percentage of time ( $\mathrm{tTa} \%)$ in which the air temperature falls within intervals derived from the comfort zone for the operative temperature was evaluated. Figure 16 shows the proposed index considering the value of air temperature recorded in the center of room, in each period, and for all systems.

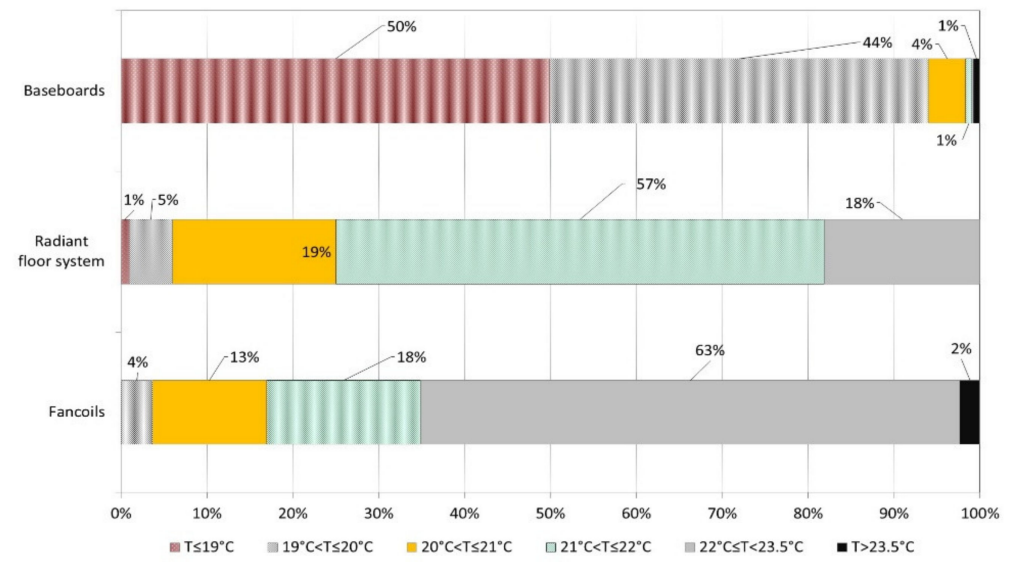

Figure 16. Percentage of time in comfort range for all systems-air temperature.

The baseboards are the more critical system, since for around $50 \%$ of monitored values, the set point is not met, and for the other hours, the air temperature is near $20^{\circ} \mathrm{C}$. Two reasons can be argued: the set-point is not adequate, or the surface covered by the baseboards is not enough and they should be installed on all four walls.

During the period with fan-coils, air temperature was for much more time in the range of $22-23.5^{\circ} \mathrm{C}(\approx 63 \%)$ than in the range of $19-21^{\circ} \mathrm{C}(\approx 17 \%)$. In the case of the radiant floor, for the previous monitoring period, the $\mathrm{T}_{\mathrm{a}_{-} \mathrm{c}}$ tended to be higher than $21{ }^{\circ} \mathrm{C}$ for $75 \%$ of time but it never exceeded $23.5^{\circ} \mathrm{C}$. With both systems, a lower set point could reduce the energy consumption by avoiding air temperature higher than the assumed set-point. This is due to the inertial properties of the radiant floor system that continues to heat the room until the water inside the pipes cools down. For the fan-coil, the effect of ventilation increases the air temperature but, as shown in the previous section, also the non-uniformity of vertical and horizontal distribution.

The statement that temperature exceeds the set point values for most of the monitored time seems to suggest that in a well-insulated structure and with good inertial properties, a management with lower set-point temperature could determine free-cost energy saving by guaranteeing at same time the respect of comfort limits.

The analysis of the proposed result must be contextualized to the quality of the building envelope that influences the uniform condition and the comfort indices. Indeed, the test-room is a particular volume with a very insulated roof and basement as well as a technical wall that can be considered quasi-adiabatic. Assuming a real application, this can be considered an office room in the middle floor of a building (upper and lower heated rooms) with three exposed walls and a room at the same temperature on the north side (technical wall). Thus, the heat losses of the opaque envelope are quite limited, and this can be considered a typical condition of the new designed highly efficient building. More in detail, the insulation level of the basement helps to favor the direction of the heat exchange when the radiative floor system is activated. Indeed, the heat losses on the ground can 
be considered null, and this is the main causes of the comparable values of $\mathrm{T}_{\mathrm{S} \text { _floor }}$ and

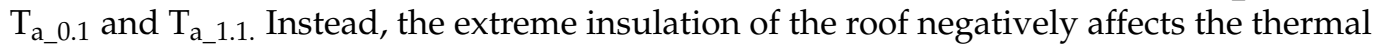
stratification with the fan-coils. Indeed, the heat exchange through the roof is also nullified, and the hot air stratifies. As regard the baseboards, these are installed on two exposed walls and also if these are well insulated (the thermal transmittance is comparable with the threshold value for Mediterranean cities), part of the radiated flow heats the walls and is exchanged with the outside. This could be one of the reasons why this system showed the least effectiveness. Probably, the location on the boundary walls with other rooms (or of the technical wall in the proposed case study) would have increased the heat exchange with the indoor air temperature.

\section{Conclusions}

The paper proposed an experimental comparison of three different heating emitters in Mediterranean climates. Thermo-hygrometric comfort was evaluated, as well as the asymmetry of vertical and horizontal distribution, considering an insulated heated volume.

The monitoring results indicate that only the baseboard system is not always able to assure comfort conditions with an operative temperature lower than $19.5^{\circ} \mathrm{C}$ for around $48 \%$ of the monitored values. However, with fan-coil units and a floor radiative system, the air temperature often rises up $20^{\circ} \mathrm{C}$ (set point value). More in particular, with a radiant floor, for $64 \%$ of the time the operative temperature is characterized by values higher than $21{ }^{\circ} \mathrm{C}$. The low value of relative humidity influences, in all analyzed cases, the calculated comfort indexes. More in general, it can be underlined that for insulated rooms in Mediterranean climates with important solar gains, the management of floor radiative systems requires a lower set-point temperature of about $1-2{ }^{\circ} \mathrm{C}$ with respect to the desired value of the air temperature, and this could bring important energy savings, without compromising the thermal comfort. Instead, when baseboards are installed, it has to be taken into account that the system requires more time to reach the set-point temperature, and thus management should consider switching on the system some hours before occupation. At the same time, the temperature values decrease more rapidly.

When the fan-coils are used, the ventilation increases the air temperature but also the non-uniformity of vertical and horizontal distribution compared with the other analyzed systems. In this case, the location of the units should be appropriately evaluated for avoiding local discomfort and for favoring the mixing of indoor air. The reduction of stratification with an appropriate design would increase the time with a high operative temperature, and this could reduce the set point temperature for obtaining a reduction of the heating consumption.

Author Contributions: Conceptualization and methodology G.P.V.; experimental monitoring and elaboration, S.R.; elaboration, writing, and editing, R.F.D.M. All authors have read and agreed to the published version of the manuscript.

Funding: This research received no external funding.

Institutional Review Board Statement: Not applicable.

Informed Consent Statement: Not applicable.

Data Availability Statement: The data presented in this study are available on request from the corresponding author. The data are not publicly available because there is not yet an easily shareable database.

Conflicts of Interest: The authors declare no conflict of interest.

\section{References}

1. ASHRAE Fundamentals. Thermal comfort. In ASHRAE Handbook; American Society of Heating, Refrigerating and Air Conditioning Engineers: Atlanta, GA, USA, 2017.

2. ASHRAE Thermal Environmental Conditions for Human Occupancy Standard 55; American Society of Heating, Refrigerating and Air Conditioning Engineers: Atlanta, GA, USA, 2013. 
3. Parsons, K.C. Environmental ergonomics: A review of principles, methods and models. Appl. Ergon. 2000, 31, 581-594. [CrossRef]

4. Liu, J.; Yao, R.; McCloy, R. A method to weight three categories of adaptive thermal comfort. Energy Build. 2012, 47, 312-320. [CrossRef]

5. International Standardization Organization. ISO 7730_Ergonomics of the Thermal Environment-Analytical Determination and Interpretation of Thermal Comfort Using Calculation of the PMV and PPD Indices and Local Thermal Comfort; ISO: Geneva, Switzerland, 2005.

6. Alfano, F.R.A.; Olesen, B.W.; Palella, B.I.; Riccio, G. Thermal comfort: Design and assessment for energy saving. Energy Build. 2014, 81, 326-336. [CrossRef]

7. Ferrantelli, A.; Võsa, K.; Kurnitski, J. Optimization of radiators, underfloor and ceiling heater towards the definition of a reference ideal heater for energy efficient buildings. Appl. Sci. 2018, 8, 2477. [CrossRef]

8. Gorni, D.; Visioli, A. Genetic algorithms based reference signal determination for temperature control of residential buildings. Appl. Sci. 2018, 8, 2129. [CrossRef]

9. Gendelis, S.; Jakovics, A.; Ratnieks, J. Thermal comfort condition assessment in test buildings with different heating/cooling systems and wall envelopes. Energy Proced. 2017, 132, 153-158. [CrossRef]

10. Lin, B.; Wang, Z.; Sun, H.; Zhu, Y.; Ouyang, Q. Evaluation and comparison of thermal comfort of convective and radiant heating terminals in office buildings. Build. Environ. 2016, 106, 91-102. [CrossRef]

11. Da Silva Júnior, A.; Mendonça, K.C.; Vilain, R.; Pereira, M.L.; Mendes, N. On the development of a simplified model for thermal comfort control of split systems. Build. Environ. 2020, 179, 106931. [CrossRef]

12. Han, Y.; Li, Z.; Xu, P. Comparative study on energy consumption of gas-fired infrared radiant and convection heating. Adv. Mater. Res. 2014, 953, 849-853. [CrossRef]

13. Karmann, C.; Schiavon, S.; Graham, L.T.; Raftery, P.; Bauman, F. Comparing temperature and acoustic satisfaction in 60 radiant and all-air buildings. Build. Environ. 2017, 126, 431-441. [CrossRef]

14. Zeiler, W.; Boxem, G. Effects of thermal activated building systems in schools on thermal comfort in winter. Build. Environ. 2009, 44, 2308-2317. [CrossRef]

15. Inard, C.; Meslem, A.; Depecker, P. Energy consumption and thermal comfort in dwelling-cells: A zonal-model approach. Build. Environ. 1998, 33, 279-291. [CrossRef]

16. Petráš, D.; Kalús, S. Effect of thermal comfort/discomfort due to infrared heaters installed at workplaces in industrial buildings. Indoor Built Environ. 2000, 9, 148-156. [CrossRef]

17. Ghaddar, N.; Salam, M.; Ghali, K. Steady thermal comfort by radiant heat transfer: The impact of the heater position. Heat Transf. Eng. 2006, 27, 29-40. [CrossRef]

18. Léger, J.; Rousse, D.R.; Le Borgne, K.; Lassue, S. Comparing electric heating systems at equal thermal comfort: An experimental investigation. Build. Environ. 2018, 128, 161-169. [CrossRef]

19. Tye-Gingras, M.; Gosselin, L. Comfort and energy consumption of hydronic heating radiant ceilings and walls based on cfd analysis. Build. Environ. 2012, 54,1-13. [CrossRef]

20. Sevilgen, G.; Kilic, M. Numerical analysis of air flow, heat transfer, moisture transport and thermal comfort in a room heated by two-panel radiators. Energy Build. 2011, 43, 137-146. [CrossRef]

21. Halawa, E.; van Hoof, J.; Soebarto, V. The impacts of the thermal radiation field on thermal comfort, energy consumption and control A critical overview. Renew. Sustain. Energy Rev. 2014, 37, 907-918. [CrossRef]

22. Catalina, T.; Virgone, J.; Kuznik, F. Evaluation of thermal comfort using combined CFD and experimentation study in a test room equipped with a cooling ceiling. Build. Environ. 2009, 44, 1740-1750. [CrossRef]

23. Kitagawa, K.; Komoda, N.; Hayano, H.; Tanabe, S. Effect of humidity and small air movement on thermal comfort under a radiant cooling ceiling by subjective experiments. Energy Build. 1999, 30, 185-193. [CrossRef]

24. Corgnati, S.P.; Perino, M.; Fracastoro, G.V.; Nielsen, P.V. Experimental and numerical analysis of air and radiant cooling systems in offices. Build. Environ. 2009, 44, 801-806. [CrossRef]

25. Causone, F.; Baldin, F.; Olesen, B.W.; Corgnati, S.P. Floor heating and cooling combined with displacement ventilation: Possibilities and limitations. Energy Build. 2010, 42, 2338-2352. [CrossRef]

26. Bagheri, N.; Moosavi, A.; Safii, M.B. Thermal enhancement of baseboard heaters using novel fin-tube arrays: Experiment and simulation. Int. J. Therm. Sc. 2020, 151, 106285. [CrossRef]

27. Shobi, M.O.; Salarian, H.; Nichkoohi, A.L.; Nimvari, M.E. Experimental and numerical investigations of a modified designed baseboard radiator using an air gap enhancing free convection heat transfer. J. Build. Eng. 2020, 32, 101535. [CrossRef]

28. Karmann, C.; Stefano, S.; Bauman, F. Thermal comfort in buildings using radiant vs. all-air systems: A critical literature review. Build. Environ. 2017, 111, 123-131. [CrossRef]

29. Sun, H.; Yang, Z.; Lin, B.; Shi, W.; Zhu, Y.; Zhao, H. Comparison of thermal comfort between convective heating and radiant heating terminals in a winter thermal environment: A field and experimental study. Energy Build. 2020, 224, 110239. [CrossRef]

30. Lin, C.; Liu, H.; Tseng, K.; Lin, S. Heating, Ventilation, and air conditioning system optimization control strategy involving fan coil unit temperature control. Appl. Sci. 2019, 9, 2391. [CrossRef]

31. Sánchez-García, D.; Bienvenido-Huertas, D.; Pulido-Arcas, J.A.; Rubio-Bellido, C. Analysis of energy consumption in different European cities: The Adaptive Comfort Control Implemented Model (ACCIM) considering Representative Concentration Pathways (RCP) scenarios. Appl. Sci. 2020, 10, 1513. [CrossRef] 
32. Date, J.; Athienitis, A.K.; Fournier, M. A study of temperature set point strategies for peak power reduction in residential buildings. Energy Proced. 2015, 78, 2130-2135. [CrossRef]

33. Wang, Z.; de Dear, R.; Lin, B.; Zhu, Y.; Ouyang, Q. Rational selection of heating temperature set points for China's hot summer e Cold winter climatic region. Build. Environ. 2015, 93, 63-70. [CrossRef]

34. Moon, J.W.; Han, S.H. Thermostat strategies impact on energy consumption in residential buildings. Energy Build. 2011, 43 , 338-346. [CrossRef]

35. Ghahramani, A.; Zhang, K.; Dutta, K.; Yang, Z.; Becerik-Gerber, B. Energy savings from temperature set-points and deadband: Quantifying the influence of building and system properties on savings. Appl. Energy 2016, 165, 930-942. [CrossRef]

36. Bienvenido-Huertas, D.; Sánchez-García, D.; Rubio-Bellido, C.; Pulido-Arcas, J.A. Influence of the improvement in thermal expectation levels with adaptive set-point temperatures on energy consumption. Appl. Sci. 2020, 10, 5282. [CrossRef]

37. Christensen, J.E.; Chasapis, K.; Gazovic, L.; Kolarik, J. Indoor environment and energy consumption optimization using field measurements and building energy simulation. Energy Proced. 2015, 78, 2118-2123. [CrossRef]

38. Hang, L.; Kim, D. Enhanced model-based predictive control system based on fuzzy logic for maintaining thermal Comfort in IoT Smart Space. Appl. Sci. 2018, 8, 1031. [CrossRef]

39. Tushar, W.; Wang, T.; Lan, L.; Xu, Y.; Withanage, C.; Yuen, C.; Wood, K.L. Policy design for controlling set-point temperature of ACs in shared spaces of buildings. Energy Build. 2017, 134, 105-114. [CrossRef]

40. Wang, F.; Chen, Z.; Feng, Q.; Zhao, Q.; Cheng, Z.; Guo, Z.; Zhong, Z. Experimental comparison between set-point based and satisfaction based indoor thermal environment control. Energy Build. 2016, 128, 686-696. [CrossRef]

41. Nikdel, L.; Janoyan, K.; Bird, S.D.; Powers, S.E. Multiple perspectives of the value of occupancy-based HVAC control systems. Build. Environ. 2018, 129, 15-25. [CrossRef]

42. Yongchao, Z.; Honnekeri, A.; Pigman, M.; Fountain, M.; Zhang, H.; Xiang, Z.; Arens, E. Use of adaptive control and its effects on human comfort in a naturally ventilated office in Alameda, California. Energy Build. 2019, 203, 109435.

43. Aftab, M.; Chen, C.; Chau, C.; Rahwan, T. Automatic HVAC control with real-time occupancy recognition and simulation-guided model predictive control in low-cost embedded system. Energy Build. 2017, 154, 141-156. [CrossRef]

44. Ascione, F.; De Masi, R.F.; de Rossi, F.; Ruggiero, S.; Vanoli, G.P. MATRIX, a multi activity test-room for evaluating the energy performances of 'building/HVAC' systems in Mediterranean climate: Experimental set-up and CFD/BPS numerical modelling. Energ. Buildings 2016, 126, 424-446. [CrossRef]

45. Zhou, X.; Liu, Y.; Luo, M.; Zhang, L.; Zhang, Q.; Zhang, X. Thermal comfort under radiant asymmetries of floor cooling system in $2 \mathrm{~h}$ and $8 \mathrm{~h}$ exposure durations. Energ. Build. 2019, 188-189, 98-100. [CrossRef]

46. Fanger, P.O.; Banhidi, L.; Olesen, B.W.; Langkilde, G.L. Comfort limits for heated ceilings. ASHRAE Trans. 1980, 86, 141-156. 